\title{
Contractual Imperfections and the Impact of Crises on Trade: Evidence from Industry-Level Data
}

\author{
Renzo Castellares ${ }^{1}$ and Jorge Salas ${ }^{2}$ \\ ${ }^{1}$ Banco Central de Reserva del Perú \\ ${ }^{2}$ International Monetary Fund
}

\author{
DT. N²016-001 \\ Serie de Documentos de Trabajo \\ Working Paper series \\ Abril 2016
}
Los puntos de vista expresados en este documento de trabajo corresponden a los autores y no reflejan necesariamente la posición del Banco Central de Reserva del Perú.




\title{
Contractual Imperfections and the Impact of Crises on
}

\section{Trade: Evidence from Industry-Level Data*}

\author{
Renzo Castellares ${ }^{1} \quad$ Jorge Salas ${ }^{2}$
}

February 16, 2016

\begin{abstract}
We build a simple trade model in which: (i) exporters are paid after delivery of the goods, and (ii) complementarity exists between procyclical contract enforcement at the importing-country level and contractual vulnerability at the industry level. In the model, an adverse aggregate shock in the importing country generates a disproportionate decline in imports in more contractually vulnerable industries. Using disaggregated bilateral trade data for more than 100 countries, we find robust support for the model's predictions. Our empirical approach exploits the variation in the occurrence of recessions and financial crises across countries from 1989 to 2006, and the variation in contractual dependence across manufacturing industries. The estimated amplification effects of contractual dependence on sectoral imports are statistically significant and economically important. Our analysis uses different industry measures of contractual vulnerability, including measures of product complexity and a novel indicator of uncollectible credit sales.
\end{abstract}

JEL Codes: F1, F41, G01, G32

Keywords: Trade, recessions, financial crises, contract enforcement, default risk, industry-level data

${ }^{*}$ We are grateful to James Harrigan, Sebnem Kalemli-Özcan, Nuno Limão, John McLaren, Ariell Reshef, John Shea, and participants at the 2015 LACEA-LAMES Meetings and the 2015 Congress of the Peruvian Economic Association for helpful comments.

${ }^{1}$ Central Bank of Peru. Jr. Antonio Miro Quesada 441, Lima 1, Peru. Phone: (+51-1)613-2000, x3939. Email: renzo.castellares@bcrp.gob.pe

${ }^{2}$ International Monetary Fund. 700 19th St. NW, Washington, DC 20431, USA. Phone: (+1)202623-5549. Email: jsalas@imf.org 


\section{Introduction}

Recent papers document the negative impact of crises on international trade. For example, Abiad et al. (2014) find empirically that financial crises are associated with significant declines in exports to the crisis country. In this paper, we argue that contractual imperfections are important to understand the causality between crises and trade disruptions. Our main finding is that exports to destinations in crisis are disproportionately affected in industries that are more contractually vulnerable. In this way, we provide empirical evidence on a new mechanism that has been thus far ignored in the literature on crises and trade.

We first propose a simple model of trade to explain the relevance of industries' contractual dependence during crises. ${ }^{1}$ Our theory builds on the intuition that when international transactions are arranged in post-shipment terms (i.e., exporters are paid by importers after delivery of the goods), the risk of default of importers matters (Schmidt-Eisenlohr, 2013). Importers are presumably less likely to honor their contracts when the state of their country's economy is weak, as would be the case if the economy were hit by a recession or if it entered into a financial crisis. But the probability of repayment under post-shipment terms can also be affected by industry-specific characteristics. In particular, when goods are more complex and/or customized, it is harder to verify their quality in court and their market value inside the original importer-exporter relationship is higher than outside this relationship. Therefore exporters in some industries are more contractually vulnerable than in others. ${ }^{2}$ We then show that when an importing country suffers an adverse aggregate shock, a complementarity between contract enforcement at the country level and contract dependence at the industry level gives rise to a larger decline in imports in more

\footnotetext{
${ }^{1}$ Throughout the paper we use the expressions "contractual vulnerability" and "contractual dependence" interchangeably.

${ }^{2}$ Some important references in the literature on incomplete contracts include Williamson (1979), Williamson (1985), Grossman and Hart (1986), and Hart and Moore (1999). See Berkowitz et al. (2006) for an early study of the relationship between product complexity, contracting institutions, and trade.
} 
contractually vulnerable industries. This is our key theoretical insight.

Using disaggregated bilateral trade data, we quantify the importance of contractual dependence at the industry level during crises. Our empirical approach exploits the variation in the occurrence of crises across 131 importing countries from 1989 to 2006, and the variation in contractual vulnerability across (up to) 351 SIC manufacturing industries. We simultaneously use three measures of crises in our regressions: recessions alone, financial crises alone, and recessions with financial crises. We confirm the negative average effects of crises on trade flows found in previous papers, but we also show that trade declines disproportionately in more contract-dependent industries. In most of our estimates, these sectoral effects are statistically significant and economically important. This finding constitutes the central contribution of the paper.

We find that when crises involve recessions with financial disruptions, the amplification effects of contractual dependence at the industry level are particularly strong. According to one of our estimates, a recession with financial crisis is associated with a $7.2 \%$ larger drop in imports in an industry that is highly contract dependent relative to an industry that exhibits little dependence. To put this result in perspective, we find that the average impact of a recession with financial crisis on sectoral imports is close to $-16 \%$, while the analogous estimates in the case of a financial crisis alone and a recession alone are nearly $-4 \%$ and $-2 \%$, respectively. $^{3}$

Our main empirical results are mostly robust to the following exercises: (i) using different sets of fixed effects, (ii) controlling for industry measures of financial vulnerability, (iii) controlling for industry measures of cyclicality (or durability), (iv) controlling for an industry measure of upstreamness, and (v) controlling for an industry measure of product differentiation. We also find evidence that in countries with lower institutional quality (proxied by the rule of law) the amplification effect of contractual vulnerability on sec-

\footnotetext{
${ }^{3}$ Our definition of recessions is based on the methodology of Braun and Larrain (2005) and our definition of financial crises relies on Laeven and Valencia (2013).
} 
toral imports tends to be greater. In addition, we report that conditional on a crisis in the importing country, a longer distance between trading partners further magnifies the sectoral trade effects of contractual imperfections.

We use three industry measures of contractual vulnerability. Two of them are standard in the literature. The first one is the Nunn (2007) index of contract-intensity of goods, measured by the value share of inputs that Nunn identifies as relationship-specific. Levchenko (2007) provides us with a second indicator, which he constructs as an index of input-use concentration. Levchenko explicitly points out that his index represents a measure of product complexity; in our paper, as in Krishna and Levchenko (2012) and Hoefele et al. (forthcoming), we make a similar assumption in terms of the Nunn index. We introduce an additional novel measure of contractual vulnerability, which we call the "uncollectible index". By quantifying the share of total account receivables uncollected compared to what was available to collect in a given period, the uncollectible index directly reflects payment defaults in business-to-business transactions. We obtain the data to construct this indicator from the National Summary of Domestic Trade Receivables, a proprietary quarterly survey of large U.S. firms. Our results are robust to the use of the Nunn, the Levchenko, and the uncollectible indices.

As summarized in Antràs (2015), several difficulties underlie the contractual imperfections associated with international transactions. First, it is sometimes difficult to determine which country's laws apply to a particular contract, especially since many contracts do not include a choice-of-law clause. Second, there is potential bias of courts in favor of their national citizens. Third, it is practically impossible in many cases to enforce decisions stipulated in a court's verdict. Recent coordinated attempts to reduce the contractual risk involving international transactions - notably, the Contracts for the International Sale of Goods initiative, and resorting to international arbitrators such as the International Chamber of Commerce-have fallen short of their objectives and constitute partial solutions at best. Quoting Rodrik (2000), Antràs (2015) concludes that 
ultimately international contracts remain incomplete.

This paper is related to the literature on the impact of financial crises and recessions on trade (Levchenko et al., 2010; Eaton et al., 2011; Berman et al., 2012; Bricongne et al., 2012; Chor and Manova, 2012; Bems et al., 2013; Abiad et al., 2014). A large part of this literature analyzes the so-called Great Trade Collapse of 2008-09. These papers have documented the role of several mechanisms, such as composition effects, supply chains, credit constraints, protectionism, and exchange rate dynamics. Our work contributes to this literature by emphasizing a new mechanism - i.e., contractual imperfections - that helps explain the important effects of crises on trade, and the heterogeneous impact across industries.

Our theoretical mechanism heavily relies on the role of default risk in trade. Other recent papers also study the implications of importers' repayment probability, but they mainly focus on a different problem, namely how this risk affects the choice of financing terms that support international trade (Hoefele et al., forthcoming; Schmidt-Eisenlohr, 2013; Ahn, 2014; Antràs and Foley, 2015). ${ }^{4}$

Finally, this paper is connected to the literature on contracting institutions and trade (see Nunn and Trefler, 2014 and Antràs, 2015 for comprehensive reviews). A large bulk of this research has documented that contracting institutions are an important determinant of comparative advantage. Levchenko (2007) and Nunn (2007) constitute seminal contributions to that literature. Our use of the contractual-vulnerability indices introduced in those two papers to analyze the effects of crises on trade is new relative to previous work.

The rest of the paper is organized as follows. Section 2 describes the theoretical framework and shows its main testable implications. Section 3 presents the empirical methodology and describes the data. Section 4 discusses the main results and several robustness exercises. Section 5 concludes.

\footnotetext{
${ }^{4}$ Financing terms used in international transactions encompass open account terms (payment after delivery), cash in advance terms or prepayment, and bank-intermediated payments (e.g., letter of credit terms and documentary collection terms).
} 


\section{A simple framework of trade and contractual im- perfections}

To fix ideas, we propose a static, partial equilibrium model of trade. The model incorporates contractual frictions in a reduced-form way, which reflect contracting imperfections affecting the outputs produced by different industries. We then use the model to derive our main testable implications. ${ }^{5}$

\subsection{Setup}

Basic assumptions. Our framework is in line with the traditional monopolistic competition models of trade. In each country, a continuum of firms produce differentiated goods in multiple industries (sectors), indexed by $s$, using labor (supplied inelastically). A numeraire sector produces a freely-traded homogeneous good under constant returns to scale. Relative wages are pinned down by productivity in this numeraire sector. Preferences are identical across countries and are described by a Cobb-Douglas utility function. For country $i$, the utility function is $U_{i}=\prod_{s} C_{i s}^{\mu_{s}}$, defined over CES consumption indices $C_{i s}=\left(\int_{\Omega_{i s}} x_{i s}(\omega)^{(\sigma-1) / \sigma} d \omega\right)^{\sigma /(\sigma-1)}$, where $\omega$ is a variety, $\Omega_{i s}$ is the set of available varieties, $\sigma>1$ is the elasticity of substitution, and $\mu_{s}$ is the sectoral expenditure share.

Production technology in the differentiated sectors exhibits increasing returns to scale. A firm from sector $s$ in country $e$ that sell $x_{e i s}$ units of a good to an importer in country $i$ faces the cost function $w_{e} \tau_{e i} x_{e i s}+f_{e i}$, where $w_{e}$ is the wage rate, $\tau_{e i}>1$ is an iceberg trade cost, and $f_{e i}$ is a fixed cost to export in units of the numeraire.

Post-shipment payment. We assume that exporters are risk neutral and use open account contracts, meaning that they are paid by importers after delivery of the goods. (Importers can be thought as wholesalers who sell to domestic consumers.) Using trade

\footnotetext{
${ }^{5}$ For simplicity the model is written in terms of final goods, but its key implications could be generalized for transactions involving intermediate inputs.
} 
data at the transaction level, Antràs and Foley (2015) (U.S.) and Ahn (2014) (Chile and Colombia) show that in terms of payment methods, open account contracts comprise the majority of international transactions, both by number and by value. Asmundson et al. (2011) report a similar finding for worldwide trade based on survey data.

Contractual frictions. Importers in country $i$ are assumed to honor their contractual obligations (i.e., pay in full and on time to exporters) with probability $\lambda_{i}$. We assume that this probability increases with aggregate real expenditure in the importing country, $Y_{i}$. That is, $\lambda_{i}$ is procyclical: $\lambda_{i}=\lambda\left(Y_{i}\right)$, with $\lambda^{\prime}\left(Y_{i}\right) \equiv \frac{\partial \lambda_{i}}{\partial Y_{i}}>0$.

A simple way to interpret this assumption is that in the wake of an adverse aggregate demand or financial shock in country $i$, some importing firms become insolvent or illiquid and are unable to pay in full and/or on time. In support of this argument, Mora and Powers (2011) document the increased perception of counterparty risk among international traders during the 2008 crisis, evidenced by the fact that exporters raised their demand for low-risk financing. Similarly, Auboin and Engemann (2014) use a comprehensive database of export credit insurance covering 91 countries and find that the risk of international trade, as proxied by claims paid on insured open account contracts, steadily increased during the acute phase of the 2008 crisis. Additionally, Jacobson et al. (2013) use data on Swedish businesses and document that the output gap is a good predictor of firm insolvency.

In the context of models of trade financing terms, Schmidt-Eisenlohr (2013) and Antràs and Foley (2015) propose a related setup in which $\lambda_{i}$ represents instead a structural index of the quality of contracting institutions in country $i$. In one of our empirical exercises below, we take that modeling approach into account by dividing our sample of importing countries into two groups: countries with weak and strong rule of law.

We also assume that contract enforcement has an additional industry-specific dimension, captured by the index $z_{s} \in[0,1]$. A higher value of $z_{s}$ implies that the good $s$ is more contract dependent, in the sense that it is more complex and hence more sensitive to im- 
perfect contracting. Intuitively, complex goods require a high share of relationship-specific inputs and often involve customization. Moreover, the quality of a complex good can be difficult to verify in court. Importers of this type of goods are thus more likely to renege on the contract due to disagreement on the quality of the delivered products. ${ }^{6}$ Further, due to their customized nature, complex goods may be hard to resell, so their market value outside the original importer-exporter relationship arguably declines following an importer's default.

As in Hoefele et al. (forthcoming), we assume complementarity between contract enforcement at the importing-country level and contract dependence at the industry level. In particular, we assume that the probability of enforcement in country $i$ and sector $s$ is given by $\overline{\lambda_{i s}}=\lambda_{i}^{z_{s}}$. For a given $\lambda_{i}$, higher values of $z_{s}$ associated with more complex goods imply a lower effective probability of contract enforcement in country $i$. For the least contract dependent product, $z_{s}=0$, the importer in country $i$ honors the contract with probability $\overline{\lambda_{i s}}=1 .^{7}$

The exporter's problem. An exporter in country $e$ and sector $s$ maximizes her expected profits from selling to country $i$, which are given by:

$$
\pi_{e i s}=\overline{\lambda_{i s}} p_{e i s} x_{e i s}-w_{e} \tau_{e i} x_{e i s}-f_{e i}
$$

Exporters choose prices recognizing the risk of default. Following Antràs and Foley (2015), equation (1) assumes that importers have no wealth and are protected by limited liability, so that they cannot pay beyond the market value of the purchased goods. ${ }^{8}$

\footnotetext{
${ }^{6}$ According to Boissay and Gropp (2013), a typical trade credit insurance contract covers against defaults due to insolvency, but not due to disagreement. In their analysis of trade credit defaults among French firms, Boissay and Gropp (2013) document that the most prevalent reason for defaulting on trade credit is disagreement, followed by illiquidity and insolvency.

${ }^{7}$ Hoefele et al. (forthcoming) and Demir and Javorcik (2014) find empirically that for a given quality of institutions in the importing country, more complex goods are less likely to be exported on open account terms, and more likely to be exported on cash in advance or bank-intermediated terms. Yet, using detailed exports data, Ahn (2014) (Chile and Colombia) and Demir and Javorcik (2014) (Turkey) report that the share of complex goods traded on open account terms is very high - around $70 \%$ to $80 \%$.

${ }^{8}$ For a related model that incorporates explicit incentive-compatibility and participation constraints to enforce international payments, see chapter 3 in Antràs (2015).
} 
The exporter decides on the optimal price $p_{e i s}$, taking as given the demand for her va-

rieties, $x_{e i s}=\left(\frac{p_{e i s}}{P_{i s}}\right)^{-\sigma} \frac{\mu_{s} P_{i} Y_{i}}{P_{i s}}$, where $Y_{i}, P_{i}$ and $P_{i s}=\left(\int_{\Omega_{i s}} p_{i s}(\omega)^{1-\sigma} d \omega\right)^{1 /(1-\sigma)}$ are specific to the importer's country, and represent aggregate real expenditure (or, with balanced trade, real GDP), the overall consumer price index, and the price index in sector $s$, respectively. We treat $Y_{i}, P_{i}$ and $P_{i s}$ as exogenous and solve for the optimal sectoral export price and quantity decisions in partial equilibrium.

\subsection{Main theoretical predictions}

In equilibrium, the export value in sector $s$ is given by:

$$
p_{e i s} x_{e i s}=\left[\frac{\sigma}{\sigma-1} \frac{1}{\overline{\lambda_{i s}}} w_{e} \tau_{e i}\right]^{1-\sigma} \frac{\mu_{s} P_{i} Y_{i}}{P_{i s}^{1-\sigma}}
$$

Equation (2) shows that the export value $p_{\text {eis }} x_{e i s}$ is a function of standard variables (constant markup over marginal cost, relative price, and sectoral expenditure), but is also an increasing function of the probability of contract enforcement $\overline{\lambda_{i s}}$. Intuitively, the riskiness of the transaction acts as wedge on the price, and this wedge increases when the exporter is more likely to face a default. Therefore, the lower the $\overline{\lambda_{i s}}$, the higher is the optimal price $p_{\text {eis }}$ and the lower is the quantity exported to country $i, x_{e i s}$. The model thus predicts that for a given industry $s$, a "crisis" in country $i$ (represented by a decline in $Y_{i}$ ) reduces the export value to that country because of the assumed procyclical movement of $\lambda_{i}$, and hence of $\overline{\lambda_{i s}}$ (first term in equation (2)). This mechanism works on top of a direct demand effect (second term in (2)).

Furthermore, the impact of a crisis in the importing country on $p_{\text {eis }} x_{e i s}$ is amplified in more contract-dependent industries. Formally, consider the effect of the industry measure of contractual vulnerability $z_{s}$ on the export value response to a decline in $Y_{i}$. The elasticity of the sectoral export value with respect to $Y_{i}$ is:

$$
\varepsilon_{p x, s} \equiv-\frac{\partial p_{e i s} x_{e i s}}{\partial Y_{i}} \frac{Y_{i}}{p_{e i s} x_{e i s}}=(1-\sigma) z_{s} \frac{\lambda^{\prime}\left(Y_{i}\right) Y_{i}}{\lambda_{i}}-1
$$


Since $1-\sigma<0$, equation (3) shows that $\varepsilon_{p x, s}<0$. The first term on the right-hand side of (3) again indicates that, all else equal, sectoral exports fall as macroeconomic conditions in the destination country $i$ deteriorate and the country-specific probability of contract enforcement $\lambda_{i}$ decreases. But crucially, a higher value of $z_{s}$ magnifies the decline in exports in industry $s$ to country $i$. This prediction constitutes our main testable implication. Meanwhile, the second term on the right-hand side of (3) implies a unit demand elasticity, common to all industries, which naturally follows from our CES demand assumption.

In the absence of firm or consumer heterogeneity, the predictions of the model are directly applicable to country-industry trade flows.

\section{$3 \quad$ Empirical strategy}

In this section we explain the empirical methodology and describe the data to be used in the regression analysis. The sources of the data are summarized in Appendix Table A1.

\subsection{Methodology}

We estimate the following baseline equation to test the hypothesis that the negative trade effects of a crisis in the destination country are amplified in industries with higher contractual vulnerability:

$$
\begin{aligned}
\ln X_{e i s t}= & \sum_{k=1}^{3} \alpha_{k} \text { Crisis }_{i t}^{k}+\sum_{k=1}^{3} \beta_{k} \text { Crisis }_{i t}^{k} \times z_{s}+ \\
& \eta \ln G D P_{i t}+\delta \ln G D P_{e t}+\varphi \Psi_{e i t}+\gamma_{e i s}+\gamma_{t}+\gamma_{i s, 6 y}+\gamma_{e s, 6 y}+\varepsilon_{e i s t},
\end{aligned}
$$

where $\ln X_{\text {eist }}$ represents the $\log$ of exports of country $e$ to country $i$ in industry $s$ at time

t. Crisis ${ }_{i t}^{k}$ is an indicator variable that takes the value of 1 if the importing country $i$ suffers a crisis at time $t$, and 0 otherwise. The superscript $k \in\{1,2,3\}$ denotes a specific 
measure of crisis, as defined below. In line with the model, we expect the coefficients associated with crises to be negative $\left(\alpha_{k}<0\right)$. These coefficients capture the average effect of crises on industry imports of the crisis country.

We incorporate three measures of crises in the regressions. In particular, Crisis ${ }^{k}$ is defined as:

$$
\text { Crisis }^{k}=\left\{\begin{array}{ll}
\text { Recession alone } & , \text { if } k=1 \\
\text { Financial Crisis alone } & , \text { if } k=2 \\
\text { Recession and Financial Crisis } & , \text { if } k=3
\end{array},\right.
$$

where 'Recession alone' captures an economic downturn without a financial crisis, 'Financial Crisis alone' characterizes a financial disruption that is not accompanied by a recession, and 'Recession and Financial Crisis' captures the simultaneous occurrence of these two events.

To identify the amplification effect of crises in industries with higher contractual vulnerability, we include interaction terms of $\mathrm{Crisis}_{i t}^{k}$ with $z_{s}$, a demeaned index that represents the degree of contractual vulnerability of industry $s$. Our model's key prediction is that the coefficients associated with these interaction terms are negative $\left(\beta_{k}<0\right)$. That is, imports of the crisis country decline disproportionately in more contract-dependent industries. We identify $\beta_{k}$ by relying on the variation of contractual vulnerability across industries, and the occurrence (or not) of crises in importing countries across years.

Additionally, equation (4) includes the $\operatorname{logs}$ of real GDP of the importing and the exporting countries ( $\ln G D P_{i t}$ and $\ln G D P_{e t}$, respectively). These are proxies for market size and demand. Another set of controls, $\Psi_{\text {eit }}$, includes the log of the bilateral real exchange rate and a dummy variable that captures whether the trading partners have a free trade agreement at time $t$.

Finally, equation (4) includes fixed effects at the exporter-importer-industry level, $\gamma_{e i s}$, 
and at the year level, $\gamma_{t}$. It also incorporates importer-industry and exporter-industry fixed effects that are allowed to vary by 6 -year periods $\left(\gamma_{i s, 6 y}\right.$ and $\gamma_{e s, 6 y}$, respectively). The inclusion of $\gamma_{e i s}$ accounts for time-invariant bilateral characteristics such as distance, common language, contiguity or colonial links, and any specific relationship between a pair of trading partners at the industry level. ${ }^{9}$ The fixed effects $\gamma_{e i s}$ also account for the time-invariant component of the multilateral trade resistance effects (Anderson and van Wincoop, 2003), which we allow to be industry-specific. The time-varying component of multilateral resistance as well as the use of tariffs and non-tariff measures are captured by the fixed effects $\gamma_{i s, 6 y}$ and $\gamma_{e s, 6 y}$. Factors that affect all countries in the same period, such as global recessions or changes in commodity prices, are captured by the fixed effects $\gamma_{t}$

We compute clustered standard errors at the importing country-year level. Below we perform several robustness checks, including alternative specifications of fixed effects and the incorporation of additional control variables.

\subsection{Data}

Country-industry trade flows. We use annual data on bilateral trade flows obtained from the Feenstra et al. (2005) World Trade Flows database and the Comtrade database. These data are originally organized by the 4-digit Standard International Trade Classification (SITC), Revision 2. Since our key industry variables are constructed for 4-digit U.S. Standard Industrial Classification (SIC) industries, we convert the trade data to this format by replicating the concordance method from Cuñat and Melitz (2012). ${ }^{10}$

\footnotetext{
${ }^{9}$ By specific relationship we mean, for example, a situation in which the exporter may not be not selling exactly the same product to every destination, or using the same payment method to sell a product across different destinations (to the extent that payment methods remain relatively stable over time).

${ }^{10}$ We add up the value of disaggregated 10-digit Harmonized System (HS) U.S. annual exports for the period 1989-2006, using the dataset constructed by Feenstra et al. (2002). Since this dataset includes a concordance between HS, SITC and SIC categories, we are able to derive concordance weights to map the SITC codes into SIC categories. A similar procedure is also employed in Chor (2010).
} 
Our sample excludes zero trade flows, nonmanufacturing industries, and the oil sector represented by the SIC code 2911. We deflate the export flows (originally reported in current U.S. dollars) by using the world export price index from the International Financial Statistics database. The results presented below, however, are robust to using nominal trade values instead of real ones. Our final sample covers the period 1989-2006 and it includes 141 exporting countries, 131 importing countries, and (in most of the regressions) 351 SIC industries. ${ }^{11}$ We show a list of the countries included in the sample in Table 1.

Recessions and financial crises. We identify crisis periods in importing countries as years when these countries experience recessions alone, financial crises alone, or both recessions and financial crises at the same time. In line with the spirit of the theoretical model, we think of these events as periods of increasing importers' risk of default.

We use real GDP and the methodology of Braun and Larrain (2005) to construct indicators for recessions. A recession in a given country is defined following a peak-totrough criterion. A trough occurs when cyclical GDP is more than one standard deviation below zero, and a local peak associated with a trough is a year in which cyclical GDP is higher than in both the previous and the posterior years. ${ }^{12}$ We checked that our results are not affected by using other definitions of recessions, such as years of negative GDP growth rates.

We also define an indicator for financial disruptions. Following Abiad et al. (2014), we identify financial crisis episodes as periods of banking or sovereign debt crises, based on the Laeven and Valencia (2013) database. The criteria to define a systemic banking crisis in this database are: (i) significant signs of distress in the banking sector, such as liquidations, losses, and/or bank runs; and (ii) significant banking policy intervention measures in

\footnotetext{
${ }^{11}$ We start the analysis in 1989 because our concordance method relies on the SITC to SIC-87 mapping that is readily available in the Feenstra et al. (2002) dataset only since 1989 (see footnote 10). Our sample captures several clusters of recessions and crises.

${ }^{12}$ The cyclical component of GDP is computed using the Hodrick-Prescott filter with a lambda parameter value of 6.25 (Ravn and Uhlig, 2002). Whenever available, the cyclical component of GDP is constructed using data from 1960 to 2012 .
} 
response to losses in the banking system. Laeven and Valencia also report sovereign debt crises as episodes of sovereign debt default and/or restructuring. Importantly, their data shows a marked increase in the number of crises during the 1990s, a period that we fully cover in our analysis. ${ }^{13}$

Of the 131 importing countries in our sample, 107 (75) suffered a recession (financial crisis) at some point between 1989 and 2000. The mean duration of a recession is close to 2.5 years, and the mean duration of a financial crisis is almost 4 years. Focusing on the measures of crises employed in our regressions, Figure 1 shows that the share of recessions alone reaches a peak of around $30 \%$ in the early 2000s, while the maximum share of observations characterized by both recessions and financial crises is above $10 \%$. The share of financial crises is on average $8 \%$, but it tends to decline over the sample period. The graph also reveals a comovement over time between the occurrence of recessions alone and the coincidence of recessions and financial crises, although the share of recessions alone in most years is greater than that of the combination of recessions and financial crises.

In our data, the existence of a non-trivial share of observations characterized by financial crises alone in the 1990s is explained by the fact that sovereign debt crises (i.e., the years between sovereign debt defaults and restructurings) often last more years than typical recessions. On the contrary, banking crises are relatively short-lived and tend to be more closely correlated with recessions.

Using panel regressions we verify that our measures of crises are associated with an increase in the risk of default. This analysis relies on two proxies of contractual enforcement - contract viability and payment delays - which are taken from the International Country Risk Guide. ${ }^{14}$ Lower values of contract viability and payment delays

\footnotetext{
${ }^{13}$ Countries of different levels of income experienced financial crises during the 1990s (e.g., Sweden, Malaysia, Mexico, Indonesia, and Kenya).

${ }^{14}$ Contract viability measures the risk of contract modification or cancellation. Payment delays measures the risk of receiving and exporting payments from a country. Both variables are available since May 2001. The regression analysis uses annual averages for the period 2002-2012 and a similar sample of countries as those in Table 1, except for 21 countries that are not available in the International Country Risk Guide data. We include country and year fixed effects, and the log of real GDP as a control variable.
} 
indicate higher default risk. Table 2 shows that there is a negative relationship between our three measures of crises and contract viability (column 1). The estimated coefficients are statistically significant, except for the case of financial crisis alone. Similarly, a negative and significant relationship is found between two of our measures of crises and payment delays (column 2). In this case the coefficient associated with recession alone is barely positive but statistically not significant. Our estimates also indicate that recessions accompanied by financial crises have a relatively larger impact on contractual enforcement, as measured by either contract viability or payment delays.

Contractual vulnerability across industries. We need to identify industry measures of contractual vulnerability as proxies for the industry-specific components of contract enforcement described in the model. We first follow the literature and use the Nunn (2007) and Levchenko (2007) indices. ${ }^{15}$ These are available for our desired level of sectoral disaggregation and are constructed using U.S. Input-Output Tables. As is standard in related papers, we assume that the ranking of industries remains stable across countries. This is a plausible assumption to the extent that both of these indices reflect technological factors.

Nunn (2007) aims to measure the contract intensity of industries, which he defines as the fraction of an industry's intermediate inputs that are relationship-specific (i.e., that are either not traded on an organized exchange or for which no reference price exists). A higher value of the Nunn (2007) index reflects a higher degree of an industry's sensitivity to imperfect institutions. ${ }^{16}$ Some of the most contract intensive industries include Motor Vehicles and Passenger Car Bodies, Electronic Computers, and Electromedical and Electrotherapeutic Apparatus. Some of the least contract intensive industries are Poultry

\footnotetext{
${ }^{15}$ To our knowledge, there are no publicly available comprehensive datasets on firm defaults on international transactions for disaggregated industries. We thank Davin Chor for kindly sharing his data on the Nunn and the Levchenko indices at the 4-digit SIC level.

${ }^{16}$ In our analysis, the index corresponds to the $z^{r s 1}$ measure specified in Nunn (2007). We use the Nunn index that relies on the Rauch (1999) conservative classification for its construction. For more details, see Chor (2010) and its supplementary appendix.
} 
Slaughtering and Processing, Primary Smelting and Refining of Copper, and Rice Milling. These examples help illustrate the relationship between product complexity and contract dependence described in the model.

The Levchenko (2007) index measures the sensitivity of an industry to institutions such as contract enforcement and property rights. It is calculated as one minus the Herfindahl index of an industry's intermediate input use. This is an inverse measure of the concentration mix of inputs, and hence a direct measure of exposure to hold-up problems in the production process. Among the most institutionally intensive industries are Fluid Power Pumps and Motors, Small Arms Ammunition, and Surgical Appliances and Supplies; among the least institutionally intensive industries are Meat Packing Plants, Creamery Butter, and Setup Paperboard Boxes.

We also use a novel measure of uncollectible credit sales, labeled as "uncollectible index", as an additional index of industry contractual vulnerability. The source of these data is the National Summary of Domestic Trade Receivables (NSDTR), a proprietary quarterly survey of large U.S. firms compiled by the Credit Research Foundation (CRF). As detailed in Appendix B, we construct our index as $1-C E I$, where $C E I$ stands for the NSDTR's Collection Effectiveness Index. The $C E I$ is acknowledged by the CRF as the most effective measure of credit and collection performance. Our uncollectible index captures the share of total account receivables uncollected compared to what was available to collect over a quarter. The CEI is originally reported in the NSDTR as a median value for every 4-digit SIC industry that registers at least 3 respondent firms. ${ }^{17}$

The uncollectible index is advantageous for our purposes as it reflects, by construction, payment defaults in business-to-business transactions at the industry level. In this sense,

\footnotetext{
${ }^{17}$ The CRF (http://www.crfonline.org/) is a non-profit, member-run organization. Its members include a large number of Fortune 1000 corporations. The NSDTR is a unique data source of performance indicators of domestic accounts receivable, defined as claims against customers for goods sold domestically on credit, based on the answers of hundreds of Fortune 1000 U.S. firms from many industries. To our knowledge, the NSDTR has not been used in recent academic literature. In the early years of the survey, however, Seiden (1964) used it in his pioneering study of the quality of trade credit, and Nadiri (1969) employed it to calculate the delinquency rate on manufacturing accounts receivable and payable.
} 
our index is better suited to capture the role of contractual imperfections than other standard indicators of trade credit intensity, such as the ratio of accounts receivable to sales or the ratio of accounts payable to the cost of goods sold. ${ }^{18}$ To isolate the structural component of the uncollectible index we take industry medians across quarters (period 2006q1-2010q4). A ranking of industries based on the uncollectible index is displayed in Appendix Table A2.

In using the uncollectible index for our empirical analysis, we assume that domestic receivable performance can proxy for the quality of collection of foreign receivables. We also believe that since large firms are dominant in international trade, the sample of Fortune 1000 firms surveyed by the CRF are representative of firms engaged in overseas transactions. That said, we acknowledge that the uncollectible index may not be, as desired, completely exogenous from the perspective of firms. Another limitation is that we only have available data to construct this index for 110 industries.

Figure 2 shows the distribution of the index. Over one third of the industries fail to collect $10 \%$ of their receivables or less. On the opposite extreme, only about $10 \%$ of industries fail to collect $30 \%$ of their receivables or more.

Table 3 summarizes some descriptive statistics of our contractual vulnerability indices. In this Table, the Nunn index is reported as "Complexity" and the Levchenko index appears as "Concentration". We maintain this notation in our regression analysis below. As shown in Table 4, our three indices are positively and significantly correlated at the $1 \%$ level. We find the highest correlation coefficient between the complexity and the concentration indices. (Tables 3 and 4 also report statistics and pairwise correlations for other industry indicators that are described below.)

Country-level data. As part of our set of control variables, we use information on

\footnotetext{
${ }^{18} \mathrm{As}$ part of our robustness checks, we control for the cash conversion cycle, an industry measure of financial dependence constructed as $365 \times$ accounts receivable/sales $-365 \times$ accounts payable/cost of goods sold $+365 \times$ inventories/cost of goods sold.
} 
Free Trade Agreements (FTA) from de Sousa (2012). The bilateral real exchange rate is constructed using data from the Penn World Table 8.1 (Feenstra et al., 2015). The source of the real GDP series is the World Development Indicators database.

Table 5 displays summary statistics for all of the country-level variables, including our indicators of crises. The Table also includes statistics for other variables that are used in the sensitivity analysis.

\section{Results}

This section shows the results of estimating our baseline regression and different robustness exercises. The number of data points in most of the regressions is above 10 million. When we use the uncollectible index as our contractual-vulnerability measure, the number of observations decreases because fewer industries have values for this index relative to Nunn's (2007) complexity and Levchenko's (2007) concentration indices. ${ }^{19}$

\subsection{Baseline results}

Table 6 presents the results of the OLS estimation of equation (4), using our three industry indices of contractual dependence. We first note that the coefficients on the control variables are statistically significant and have the expected signs.

In column 1, we show that when a country is hit by a crisis, the average impact on its industry imports is negative, even after controlling for demand. Following the notation of equation (4), the point estimate of $\alpha_{k}$ is statistically significant when a crisis is measured by a recession alone $\left(\alpha_{1}\right)$, a financial crisis alone $\left(\alpha_{2}\right)$, or a a financial crisis accompanied by a recession $\left(\alpha_{3}\right)$. In terms of magnitude, industry imports of the crisis country decline on average $1.7 \%(\exp (-0.017)-1)$ following a pure recession, $4.4 \%(\exp (-0.045)-1)$

\footnotetext{
${ }^{19}$ Our panel is unbalanced since not all countries trade in all industries and years. Moreover, not all of our control variables are available for every country over the entire sample period.
} 
following a financial crisis, and $15.7 \%(\exp (-0.171)-1)$ in the aftermath of a recession with financial crisis. Our estimate of the combined effect of recessions and financial disruptions on imports is fairly similar to the findings of Abiad et al. (2014). They document that in the year after a crisis, imports fall, on average, $19 \%$.

Once we include the interactions of the crisis indicators with our industry measures of contractual vulnerability (columns 2-4 in Table 6), we observe that the estimated coefficients on these interaction terms are negative $\left(\beta_{k}<0\right)$. All of the coefficients are highly statistically significant, except for the interaction of financial crisis alone with the uncollectible index. Therefore we confirm our key hypothesis that imports in more contract-dependent industries are disproportionately affected by crises. This result is robust to the use of the complexity, concentration, or uncollectible indices (except when the uncollectible index interacts with financial crisis alone, as noted above). For the case of the complexity index, our estimates imply that a one-standard-deviation increase from its mean magnifies the decline in imports from $1.6 \%$ to $2.6 \%$ following a recession alone, from $4.3 \%$ to $6.2 \%$ following a financial crisis alone, and from $15.4 \%$ to $19.2 \%$ following a recession and financial crisis. $^{20}$

To further explore the amplification effect induced by contractual vulnerability at the industry level, we use our estimates for $\beta_{k}$ and compare the differential impact of crises on trade across two specific industries. We define an industry in the $25^{\text {th }}$ percentile of each contractual-vulnerability index as a 'slightly contract-dependent' industry. Similarly, we define an industry in the $75^{\text {th }}$ percentile of each contractual-vulnerability index as a 'highly contract-dependent' industry.

As summarized in Table 7, a recession with financial crisis generates the largest amplifications effects on industry imports (column 3). In particular, focusing on the complexity

\footnotetext{
${ }^{20}$ Analogously, the magnification effects on imports for the case of the concentration index are from $1.6 \%$ to $3.4 \%$ (recession alone), from $4.3 \%$ to $5.8 \%$ (financial crisis alone), and from $15.4 \%$ to $18.4 \%$ (recession and financial crisis). For the uncollectible index, those effects are from $1.4 \%$ to $3.3 \%$ (recession alone), from $4.1 \%$ to $4.9 \%$ (financial crisis alone), and from $15.3 \%$ to $17.7 \%$ (recession and financial crisis).
} 
index, the impact of a recession and financial crisis is 7.2 percentage points $(\exp (-0.075)-$ 1) larger in the highly contract-dependent industry (Printed Circuit Boards, SIC 3672) than in the slightly contract-dependent industry (Steel Works, Blast Furnaces, and Rolling Mills, SIC 3312). For the uncollectible index, the industry with high contract dependence exhibits a 4 percentage points $(\exp (-0.041)-1)$ larger drop in imports than the industry with low dependence (Construction Machinery and Equipment, SIC 3531; and Paper Mills, SIC 2621, respectively) following a recession and financial crisis. All the reported differences between the $75^{\text {th }}$ and the $25^{\text {th }}$ percentiles are statistically significant (at the $1 \%$ level), except when we use the interaction of financial crisis alone with the uncollectible index. The amplification effects conditional on a recession and financial crisis are larger than those associated with a recession alone (column 1) and a financial crisis alone (column 2), roughly by a factor of 2.7 , on average.

The key baseline results are robust to the use of alternative sets of fixed effects, as shown in Table 8. Columns 1-3 correspond to a specification that omits the time-variant dimension of the multilateral trade resistance term, while the regressions in columns 4-6 omit the year fixed effects but include exporter-year and importer-year fixed effects. In the latter regressions, the newly introduced fixed effects subsume the average impact of crises on industry imports, so we are no longer able to identify the parameter $\alpha_{k}$. Two differences with respect to the baseline results are worth noting. First, in columns 1-3, the average impact on industry imports of recessions (measured by the point estimates of $\left.\alpha_{1}\right)$ is greater than in the baseline model, whereas the average impact of financial crises $\left(\alpha_{2}\right)$ is not statistically significant. Second, the coefficients attached to the interactions of the concentration index with both the financial crisis alone indicator and the recession and financial crisis indicator are approximately twice as high as in the baseline results. 


\subsection{Sensitivity analysis: additional control variables}

Although our use of controls and fixed effects in the baseline equation aims to mitigate concerns about omitted variables, we next allow for the possibility that our industry measures of contractual vulnerability may pick up the effect of other factors. Thus we verify the sensitivity of our results to the introduction of additional interaction terms. For the remainder of this section, all of the regressions include the same control variables as the baseline estimation, but to save space they are omitted in the tables.

\subsubsection{Controlling for financial vulnerability}

A financially dependent industry could be affected by credit constraints as a result of facing high fixed costs or significant working capital needs. In this exercise, we separately include interaction terms of our crisis indicators with standard measures of financial dependence, which are based on data from Compustat's annual industrial files (period 1995-2012).

The first industry measure of financial vulnerability is the cash conversion cycle (CashCycle), a proxy for short term financial needs to cover net working capital, defined as the period between a firm's payment for materials and the collection of its sales (Raddatz, 2006). The second one is a measure of asset tangibility (TangAssets), namely the share of net property, plant and equipment in total book-value assets (Braun, 2003). ${ }^{21}$ Industries with higher values of CashCycle and with lower values of TangAssets are more financially dependent. Table 3 reports summary statistics for these variables and Table 4 shows that there are some statistically significant correlations between the contractual and the fi-

\footnotetext{
${ }^{21}$ We drop firm-year observations with negative or missing values on sales and assets from the Compustat sample. To reduce the effect of outliers, we first sum each firm's value of net property, plant and equipment over the sample period and then divide by the sum of assets over the sample period in order to construct TangAssets. An analogous procedure is followed to aggregate over time the ratios involved in the construction of CashCycle. We then trim both $1 \%$ tails of the firm distributions for each of the three measures and calculate industry medians. To gain observations, whenever a median value is not available for a SIC-4 industry, we impose the median value computed for the immediately higher level of aggregation (SIC-3).
} 
nancial vulnerability indicators. Notably, the complexity index exhibits a somewhat high negative correlation with TangAssets and a positive correlation with CashCycle.

The inclusion of the financial vulnerability indicators does not substantially change our findings, although the magnitudes of most of the interaction coefficients for the contractual-dependence measures decline (in absolute value) when we use CashCycle. The results obtained with CashCycle and TangAssets are presented in Table 9 and Appendix Table A3, respectively. The majority of the coefficients on the interactions of CashCycle and TangAssets with the crisis indicators have the expected signs (i.e., negative and positive, respectively). In several cases, these coefficients are also statistically significant. Hence, the bulk of our results imply that trade in more financially-dependent industries is more negatively affected during crises, which is consistent with the evidence in Chor and Manova (2012).

In unreported regressions, we also experiment with the Rajan and Zingales (1998) index of external finance dependence (i.e., the ratio of the difference between capital expenditures and cash flow over capital expenditures) as an additional measure of financial vulnerability. Our findings do not show a statistically significant role for this variable, while the rest of our key results remain unchanged.

\subsubsection{Controlling for cyclicality}

Compositional effects and durability play a role in explaining trade collapses in the aftermath of recessions and financial crises (see, e.g., Levchenko et al., 2010, and Eaton et al., 2011). This is because international trade is intensive in certain product categories, such as investment and durable consumption goods, that are more sensitive to cyclical fluctuations than other goods. We next evaluate the robustness of our results to the inclusion of interaction terms of the crisis indicators with dummy variables representing (loosely speaking) cyclical and noncyclical goods.

We construct two dummy variables using the mapping of 4-digit SIC industries to 
categories of final demand from Gomes et al. (2009). Our first dummy variable (labeled as "Cyclical (with NX)" in Table 10) takes the value of 1 (cyclical) if the industry is categorized by Gomes et al. (2009) as durable consumption, investment, or net exports; and takes the value of 0 (noncyclical) if the industry is categorized as nondurable consumption, government consumption and investment, or consumption of services. Alternatively, a second dummy variable (labeled as "Cyclical (exc. NX)" in Table 10) is constructed in the same way except that the category net exports is excluded from the cyclical group. ${ }^{22}$

To examine the relationship between contract dependence and cyclicality, we use our second dummy variable to split the sample of industries according to whether they are more or less cyclical. In Figure 3 we plot the distributions of the complexity and the concentration indices for each subsample. Using the first dummy variable to split the sample yields relatively similar plots. It is visually apparent that cyclical industries tend to be more contractually vulnerable than noncyclical industries. This pattern is particularly clear if we observe the plots for the concentration index. More concretely, the median values of the complexity and the concentration indices are higher for cyclical industries than for noncyclical ones. The differences between medians are statistically significant at the $1 \%$ level according to the adjusted median chi-square and the Kruskal-Wallis tests.

The results with the first and the second dummy variable are displayed in Table 10 and Appendix Table A4, respectively. We find that our baseline estimates are essentially unaffected when we account for the fact that crises can have a larger negative impact on more cyclical goods. If anything, the magnitudes of the interaction coefficients for the contractual-dependence measures decline slightly in absolute value. Moreover, when the coefficients on the interactions with the cyclicality dummies are statistically significant, recessions alone and accompanied by financial crises are found to disproportionately re-

\footnotetext{
${ }^{22}$ Gomes et al's (2009) classification covers the majority of SIC-4 industries. To gain observations, for the SIC-4 industries that are not classified by them we impose the categories of final demand corresponding to the immediately higher level of aggregation (SIC-3).
} 
duce trade in cyclical goods relative to noncyclical goods by 1 to 3 percentage points. ${ }^{23}$ These results hold using either of our two dummy variables for cyclicality.

\subsubsection{Controlling for upstreamness}

Using data on U.S. imports and exports, Levchenko et al. (2010) find that goods that are intensively used as intermediate inputs experienced significantly greater reductions in trade during the Great Trade Collapse. A natural explanation for this finding lies in the role of supply chains (or vertical linkages). That is, since input trade is increasingly predominant in world trade, a drop in final output leads potentially to a more than proportional decline in trade in intermediate goods. In a new set of regressions, we check if our results are sensitive to the addition of interactions terms of the crisis indicators with a measure of the intensity with which industries are used as intermediate inputs.

We start with one of the measures of downstreamness built by Antràs and Chor (2015), DUse_TUse, namely the ratio of aggregate direct use to aggregate total use of an industry as an input. The original data in 2002 U.S. Input-Output (I-O) industries is mapped into SIC industries using the I-O to NAICS concordance from the BEA and the NAICS to SIC concordance from the Census Bureau (the details are available upon request). We then construct a variable called "Upstreamness", equal to one minus the Antràs and Chor downstreamness measure $\left(1-D U s e \_T U s e\right)$. A high value of Upstreamness suggests that most of the contribution of a given industry to production processes occurs in more upstream stages (i.e., far from the retail end of the value chain).

The results presented in Table 11 show that our baseline estimates are roughly unchanged in these alternative regressions. Furthermore, the negative and statistically significant coefficients on the interactions with Upstreamness imply that crises have an additional negative impact on goods that are more intensely used as intermediate inputs.

\footnotetext{
${ }^{23}$ This finding is qualitatively consistent with previous evidence in the literature. For example, Abiad et al. (2014) report that the recent Great Trade Collapse caused a larger drop in trade in capital and durable goods than in consumer nondurable goods (of 10\%, on average).
} 


\subsubsection{Controlling for product differentiation}

As documented in Haddad et al. (2010) and Gopinath et al. (2012), trade quantities of differentiated goods decline relatively more than those of nondifferentiated goods during recessions, even after controlling for features such as durability and end use. This is probably because differentiated goods have a higher income elasticity of demand and more rigid prices than nondifferentiated goods. To rule out the possibility that our measures of contractual dependence may pick up the effect of product differentiation, we estimate a set of regressions that include additional interaction terms of the crisis indicators with another dummy variable.

We construct a dummy variable called "Differentiation" using the Rauch (1999) product classification. This variable takes the value of 1 if an industry is classified by Rauch as differentiated, and 0 if an industry is identified as nondifferentiated. The latter category includes goods traded in organized exchanges or with reference prices. ${ }^{24}$

Table 12 shows that the amplification effects induced by contractual vulnerability, captured by the interaction terms with our measures of contractual dependence, are in some cases moderately smaller relative to the baseline regressions. We also find evidence that financial crises alone and recessions with financial crises generate a disproportionate decline in the trade volumes of differentiated goods. According to our statistically significant results, the magnitude of this reduction is between $3 \%$ and $5 \%$.

\subsubsection{All the additional control variables together}

Building on previous exercises, we perform a sensitivity check that simultaneously includes extra interaction terms in our baseline regressions. These variables aim to control for the potentially larger effect of crises on trade in industries with higher working capital

\footnotetext{
${ }^{24}$ Since the Rauch (1999) classification is originally available at the SITC level, we previously map Rauch's categories into 4-digit SIC industries. The details of our concordance method are available upon request.
} 
necessities (CashCycle) as well as in cyclical, upstream, and differentiated goods industries (Cyclical (with NX), Upstreamness, and Differentiation, respectively).

Table 13 shows the results. Compared with the baseline regressions, we observe that adding all of the interaction terms together somewhat reduces the magnitude (in absolute value), but not the statistical significance, of the coefficients attached to the interactions with the contractual dependence measures. Such reduction in magnitude is relatively important for some of the interactions terms that involve the concentration and uncollectible indices, but is much less significant for the interactions with the complexity index.

\subsection{Contract enforcement (rule of law) at the country level}

We now test if the decline of imports among industries with higher contractual dependence is more pronounced in countries with lower structural levels of contractual enforcement. This would be a reasonable outcome if, independently of the industry, importing firms were more likely to default in countries with worse institutional quality (see, e.g., SchmidtEisenlohr, 2013); or alternatively, if poor institutions disproportionately exacerbated the risk of default of more contract-dependent industries. To measure a country's ability to enforce contracts we use the rule of law index from Kaufmann et al. (2010). We then split the sample according to whether importing countries are above or below the median value of this indicator. The results are shown in Table 14 .

According to most of the point estimates of $\beta_{k}$, the amplification effects due to contractual vulnerability at the industry level are indeed larger in countries with low contract enforcement. This conclusion is particularly robust when we use the concentration index (columns 3 and 7). Illustratively, the coefficient attached to the interaction of the recession and financial crisis indicator and the concentration index is $43 \%$ larger (in absolute value) in the low-enforcement sample than in the high-enforcement sample $(-0.382$ and -0.267 , respectively). A similarly robust conclusion emerges when crises are proxied by 
recession alone, regardless of the specific measure of contractual dependence. However, the evidence is more mixed when crises are measured by financial crisis alone.

We also note that crises have a larger average impact on sectoral imports of countries with low contract enforcement (columns 1 and 5). For example, in the wake of recessions alone, the estimated average drop in imports for this group of countries is $5 \%$ $(\exp (-0.051)-1)$, compared to a negligible impact in countries with high enforcement.

\subsection{The role of distance}

Antràs and Foley (2015) emphasize that the effects of contractual imperfections on trade increase with distance. They argue that at least in some industries, when the importer defaults, exporters' main recourse involves shipping the goods back to their home country, but those costs rise with distance. In our final empirical exercise, we analyze if a longer bilateral distance magnifies the decline in imports stemming from the interaction of crises in the destination country and contractual dependence at the industry level. To do so, we incorporate in our baseline equation interaction terms between the crisis indicators, the industry indices of contractual dependence, and the (demeaned) geographical distance between exporting and importing countries. ${ }^{25}$

Table 15 displays the results. In line with Antràs and Foley (2015), the estimated coefficients on the newly introduced triple interaction terms are negative, indicating that distance amplifies the effects on sectoral trade of industries' contractual vulnerability during crises. Importantly, seven out of these nine coefficients are statistically significant (the exceptions being the coefficients attached to the triple interaction terms that include recession alone in columns 2 and 3).

To quantify the amplification effects induced by distance, consider for illustrative

\footnotetext{
${ }^{25}$ Bilateral distance is measured as the distance between the capitals of two countries. The data is taken from the CEPII distance database. In this set of regressions we also include the double interaction terms Recession alone $\times$ Distance, Fin.Crisis alone $\times$ Distance, and Recession $\&$ Fin. Crisis $\times$ Distance.
} 
purposes the case of a highly contract-dependent industry such as Printed Circuit Boards ( $75^{\text {th }}$ percentile of the complexity index) and the occurrence of a recession with financial crisis in the importing country. All else equal, our estimates from Table 15 imply that increasing the distance between trading partners by 5000 kilometers (equivalent to 3107 miles) amplifies the decline in sectoral imports by 2.6 percentage points (significant at the 1 percent level). ${ }^{26}$ Not surprisingly, this amplification effect increases with the degree of contractual dependence: if in our example above, we use the $95^{\text {th }}$ percentile of the complexity index instead of the $75^{\text {th }}$ percentile, the additional 5000 kilometers of distance reduce sectoral imports by 4.3 percentage points, conditional on a recession and financial crisis. Using other measures of crises and contractual vulnerability we get qualitatively similar results, but relatively smaller amplification effects.

\section{Conclusion}

In this paper we provide evidence on a mechanism that has been ignored in the existing literature on crises and trade. We document empirically that when countries experience recessions, financial crisis, or a combination of the two, their imports fall disproportionately in more contract-dependent industries. Put differently, contractual imperfections at the product level exacerbate the negative impact of crises on international trade. This mechanism operates on top of other relevant sources of heterogeneity across industries, such as financial dependence, degree of cyclicality, upstreamness, and product differentiation. Moreover, the estimated amplification effect of contractual vulnerability on sectoral imports appears to strengthen if the crisis country has weak rule of law. The amplification effect also strengthens with the distance between the exporting and importing countries.

We argue that these findings can be rationalized by two considerations. First, a large

\footnotetext{
${ }^{26}$ Our example uses 5000 kilometers as this is close to the median value of the bilateral distance between trading partners in our sample (5256 kilometers). Illustratively, the distance between the capitals of Brazil and Costa Rica is 4908 kilometers.
} 
share of cross-border transactions rely on post-shipment payment. Second, the risk of default of importers is affected by macroeconomic conditions and worsens in industries that are more sensitive to the quality of contracting institutions.

Our quantitative findings may seem surprising in light of some considerations that could downplay the risk of default faced by exporters. First, although post-shipment terms are the most prevalent payment method in trade, other safer alternatives include cash in advance and bank-intermediated financing terms. Second, the use of intermediaries for exporting is relatively widespread. Third, exporters may purchase insurance against defaults based on insolvency. Fourth, for the substantial fraction of trade that occurs among related parties, contractual frictions are presumably less relevant. In spite of all of these arguments, our results robustly indicate that the complementarity between contract enforcement at the importing-country and industry levels plays a significant role in shaping the response of trade to crises. We would require finer data to evaluate the importance of each of the aforementioned considerations. In addition, it would be interesting to disentangle the roles of the extensive margin and the intensive margin of trade in our story. We see our paper as a first step towards tackling those issues.

\section{References}

Abiad, A., Mishra, P., and Topalova, P. (2014). How Does Trade Evolve in the Aftermath of Financial Crises? IMF Economic Review, 62:2, 213-247.

Ahn, J. (2014). Understanding Trade Finance: Theory and Evidence from TransactionLevel Data. Unpublished. International Monetary Fund.

Anderson, J., and van Wincoop, E. (2003). Gravity And Gravitas: A Solution To The Border Puzzle. American Economic Review, 93:1, 170-192.

Antràs, P. (2015). Global Production. Firms, Contracts and Trade Structure. Unpublished.

Antràs, P., and Chor, D. (2013). Organizing the Global Value Chain. Econometrica, 81:6, 2127-2204. 
Antràs, P., and Foley, F. (2015). Poultry in Motion: A Study of International Trade Finance Practices. Journal of Political Economy, 123:4, 809-852.

Asmundson, I., Dorsey, T., Khachatryan, A., Niculcea, I., and Saito, M. (2011). Trade and Trade Finance in the 2008-09 Financial Crisis. IMF Working Paper 11/16, International Monetary Fund.

Auboin, M., and Engemann, M. (2014). Testing the Trade Credit and Trade Link: Evidence from Data on Export Credit Insurance. Review of World Economics, 150:4, 715-743.

Bems, R., Johnson, R., and Yi, K. (2013). The Great Trade Collapse. Annual Review of Economics, 5.

Berkowitz, D., Moenius, J., and Pistor, K. (2006). Trade, Law, and Product Complexity. The Review of Economics and Statistics., 88:2, 363-373.

Berman, N., de Sousa, J., Martin, P., and Mayer, T. (2012). Time to Ship during Financial Crises. NBER WP 18274.

Boissay, F. and Gropp, R. (2013). Payment Defaults and Interfirm Liquidity Provision. Review of Finance, 17:6, 1853-1894.

Braun, M. (2003). Financial Contractibility and Asset Hardness. Unpublished.

Braun, M. and Larrain, B. (2005). Finance and the Business Cycle: International, InterIndustry Evidence. Journal of Finance, 60:3, 1097-1128.

Bricongne, J., Fontagne, L., Gaulier, G., Taglioni, D., and Vicard, V. (2012). Firms and the Global Cisis: French Exports in the Turmoil. Journal of International Economics, $87: 1,134-146$.

Chor, D. (2010). Unpacking Sources of Comparative Advantage: A Quantitative Approach. Journal of International Economics, 82:2, 152-167.

Chor, D. and Manova, K. (2012). Off the Cliff and Back? Credit Conditions and International Trade during the Global Financial Crisis. Journal of International Economics, 87, 117-133.

Credit Research Foundation. National Summary of Domestic Trade Receivables, various issues.

Cunat, A. and Melitz, M. (2012). Volatility, Labor Market Flexibility, And The Pattern Of Comparative Advantage. Journal of the European Economic Association, 10:2, 225-254.

Demir, B. and Javorcik, B. (2014). Grin and Bear It: Producer-Financed Exports from an Emerging Market. Unpublished. 
de Sousa, J. (2012). The Currency Union Effect on Trade is Decreasing Over Time. Economic Letters, 117:3, 917-920.

Eaton, J., Kortum, S., Neiman, B., and Romalis, J. (2011). Trade and the Global Recession. NBER WP 16666.

Feenstra, R., Inklaar, R., and Timmer, M. (2015). The Next Generation of the Penn World Table. American Economic Review, 105:10, 3150-3182.

Feenstra, R., Lipsey, R., Deng, H., Ma, A., and Mo, H. (2005). World Trade Flows: 1962-2000. NBER WP 11040.

Feenstra, R., Romalis, J., and Schott, P. (2002). U.S. Imports, Exports and Tariff Data, 1989 to 2001. NBER WP 9387.

Gomes, J., Kogan, L., and Yogo, M. (2009). Durability of Output and Expected Stock Returns. Journal of Political Economy, 117:5, 941-986.

Gopinath, G., Itskhoki, O., and Neiman, B. (2012). Trade Prices and the Global Trade Collapse of 2008-2009. IMF Economic Review, 60:3, 303-328.

Grossman, S. and Hart O. (1986). The Costs and Benefits of Ownership: A Theory of Vertical and Lateral Integration. Journal of Political Economy, XCIV, 691-719.

Haddad, M., Harrison, A., and Hausman, C. (2010). Decomposing the Great Trade Collapse: Products, Prices, and Quantities in the 2008-2009 Crisis. NBER WP 16253.

Hart, O., and Moore, J. (1999). Foundations of Incomplete Contracts. Review of Economic Studies, 66:1, 115-138.

Hoefele, A., Schmidt-Eisenlohr, T., and Yu, Z. (forthcoming). Payment Choice in International Trade: Theory and Evidence from Cross-Country Firm Level Data. Canadian Journal of Economics.

Jacobson, T., Linde, J., and Roszbach, K. (2013). Firm Default and Aggregate Fluctuations. Journal of the European Economic Association, 11:4, 945-972.

Laeven, L. and Valencia, F. (2013). Systemic Banking Crises Database. IMF Economic Review, 61:2, 225-270.

Levchenko, A. (2007). Institutional Quality and International Trade. Review of Economic Studies, 74:3, 791-819.

Levchenko, A., Lewis, L., and Tesar, L. (2010). The Collapse of International Trade During the 2008-2009 Crisis: In Search of the Smoking Gun. IMF Economic Review, $58: 2,214-253$. 
Kaufmann, D., Kraay, A., and Mastruzzi, M. (2010). The Worldwide Governance Indicators: A Summary of Methodology, Data and Analytical Issues. World Bank Policy Research Working Paper No.5430.

Krishna, P. and Levchenko, A. (2012). Comparative Advantage, Complexity, and Volatility. Journal of Economic Behavior and Organization, 94, 314-329.

Mora, J. and Powers, W. (2011). Global Perspectives in the Decline of Trade Finance. In: Chauffour, J. and Malouche, M. (editors), Trade Finance during the Great Trade Collapse, The World Bank.

Nadiri, M. I. (1969). The Determinants of Trade Credit in the U.S. Total Manufacturing Sector. Econometrica, 37:3, 408-423.

Nunn, N. (2007). Relationship-Specificity, Incomplete Contracts, and the Pattern of Trade. The Quarterly Journal of Economics, 122:2, 569-600.

Nunn, A. and Trefler, D. (2014). Domestic Institutions as a Source of Comparative Advantage. In: Gopinath, G., Helpman, E., and Rogoff, K. (eds.), Handbook of International Economics, 4th ed.

Raddatz, C. (2006). Liquidity Needs and Vulnerability to Financial Underdevelopment. Journal of Financial Economics, 80:3, 677-722.

Rauch, J. (1999). Networks versus Markets in International Trade. Journal of International Economics, 48:1, 7-35.

Rajan, R. and Zingales, L. (1998). Financial Dependence and Growth. American Economic Review, 88:3, 559-586.

Ravn, M. and Uhlig, H. (2002). On Adjusting the HP-Filter for the Frequency of Observations. The Review of Economics and Statistics, 84:2, 371-375.

Rodrik, D. (2000). How Far Will International Economic Integration Go? Journal of Economic Perspectives, 14:1, 177-186.

Schmidt-Eisenlohr, T. (2013). Towards a Theory of Trade Finance. Journal of International Economics, 91:1, 96-112.

Seiden, Martin H. (1964). The Quality of Trade Credit. National Bureau of Economic Research.

Williamson, O. (1979). Transaction Cost Economics: The Governance of Contractual Relations. Journal of Law and Economics, XXII, 233-261.

Williamson, O. (1985). The Economic Institutions of Capitalism. The Free Press. 
Table 1

List of countries

\begin{tabular}{|c|c|c|c|}
\hline Albania & Dominican Republic & Kyrgyz Republic & Rwanda \\
\hline Angola & Ecuador & Lao PDR & Saudi Arabia* \\
\hline Argentina & Egypt, Arab Rep. & Latvia & Senegal \\
\hline Armenia & El Salvador & Lebanon & Sierra Leone \\
\hline Australia & Equatorial Guinea & Liberia & Singapore \\
\hline Austria & Estonia & Lithuania & Slovak Republic \\
\hline Azerbaijan & Ethiopia & Macao* & Slovenia \\
\hline Bahamas* & Fiji & Madagascar & South Africa \\
\hline Bahrain* & Finland & Malawi & Spain \\
\hline Bangladesh & France & Malaysia & Sri Lanka \\
\hline Barbados & Gabon & Mali & St. Kitts and Nevis* \\
\hline Belarus & Gambia & Malta* & Sudan \\
\hline Belgium & Georgia & Mauritania & Suriname \\
\hline Belize & Germany & Mauritius & Sweden \\
\hline Benin & Ghana & Mexico & Switzerland \\
\hline Bolivia & Greece & Moldova & Syrian Arab Republic \\
\hline Bosnia and Herzegovina & Guatemala & Mongolia & Tanzania \\
\hline Brazil & Guinea & Morocco & Thailand \\
\hline Bulgaria & Honduras & Mozambique & Togo \\
\hline Burkina Faso & Hong Kong & Nepal & Trinidad and Tobago \\
\hline Burundi & Hungary & Netherlands & Tunisia \\
\hline Cambodia & Iceland & New Zealand & Turkey \\
\hline Cameroon & India & Niger & Turkmenistan \\
\hline Canada & Indonesia & Nigeria & Uganda \\
\hline Central African Republic & Iran, Islamic Rep. & Norway & Ukraine \\
\hline Chad & Iraq* & Oman* & United Kingdom \\
\hline Chile & Ireland & Pakistan & United States \\
\hline China & Israel & Panama & Uruguay \\
\hline Colombia & Italy & Paraguay & Uzbekistan \\
\hline Congo, Rep. & Jamaica* & Peru & Venezuela, RB \\
\hline Costa Rica & Japan & Philippines & Vietnam \\
\hline Cote d'Ivoire & Jordan & Poland & Yemen, Rep. \\
\hline Croatia & Kazakhstan & Portugal & Zambia \\
\hline Cyprus & Kenya & Qatar* & \\
\hline Czech Republic & Korea, Rep. & Romania & \\
\hline Denmark & Kuwait & Russian Federation & \\
\hline
\end{tabular}

Notes: An asterisk $\left({ }^{*}\right)$ indicates countries that appear in the sample only as exporters. 
Table 2

Effects of crises on the enforcement of contracts

\begin{tabular}{lcc}
\hline \hline Dependent Variable: & $\begin{array}{c}\text { Contract Viability } \\
(1)\end{array}$ & $\begin{array}{c}\text { Payment Delays } \\
(2)\end{array}$ \\
\hline Recession alone & $-0.079^{* *}$ & 0.030 \\
& $(0.034)$ & $(0.024)$ \\
Fin. Crisis alone & -0.094 & $-0.158^{* * *}$ \\
& $(0.068)$ & $(0.047)$ \\
Recession \& Fin. Crisis & $-0.295^{* * *}$ & $-0.192^{* * *}$ \\
& $(0.072)$ & $(0.049)$ \\
Ln GDP & $0.466^{* * *}$ & $0.585^{* * *}$ \\
& $(0.137)$ & $(0.104)$ \\
\hline Observations & 1,129 & 1,129 \\
R-squared & 0.829 & 0.944 \\
Country FE & YES & YES \\
Year FE & YES & YES \\
\hline \hline
\end{tabular}

Notes: Robust standard errors, with ${ }^{* * *},{ }^{* *},{ }^{*}$ denoting significance at the $1 \%, 5 \%$ and $10 \%$ levels, respectively. Contract Viability measures the risk of contract modification or cancellation. Payment Delays measures the risk of receiving and exporting payments from a country. Lower values of Contract Viability and Payment Delays indicate higher risks. The source of these two variables is the International Country Risk Guide. See text for further details. 
Table 3

Summary statistics: indicators of contractual and financial vulnerability, at industry level

\begin{tabular}{lccccc}
\hline \hline Variable & Obs. & Mean & Std.Dev. & Min & Max \\
\hline Complexity & 351 & 0.56 & 0.25 & 0.00 & 0.98 \\
Concentration & 351 & 0.86 & 0.11 & 0.21 & 0.97 \\
Uncollectible & 110 & 0.17 & 0.09 & 0.02 & 0.49 \\
CashCycle & 351 & 0.94 & 0.34 & 0.30 & 2.06 \\
TangAssets & 351 & 0.40 & 0.15 & 0.14 & 0.88 \\
\hline \hline
\end{tabular}

Notes: Industries are classified by 4-digit SIC. Complexity is the input relationship-specificity index from Nunn (2007). Concentration is the input concentration index from Levchenko (2007). The source of these indices is Chor (2010). Uncollectible is the account receivables' collection ineffectiveness index, based on data from the Credit Research Foundation's National Summary of Domestic Trade Receivables. CashCycle is a measure of the time elapsed between the moment a firm pays for its materials until the collection on its sales (in hundreds of days). TangAssets is a measure of tangible assets developed by Braun (2003). The last two measures are constructed using data from Compustat. See text for further details. 
Table 4

Pairwise correlation coefficients: indicators of contractual and financial vulnerability

\begin{tabular}{lcccc}
\hline \hline & Complexity & Concentration & Uncollectible & CashCycle \\
\hline Concentration & 0.52 & & & \\
& $(0.00)$ & & & \\
Uncollectible & 0.45 & 0.26 & & \\
& $(0.00)$ & $(0.01)$ & & \\
CashCycle & 0.50 & 0.36 & 0.43 & \\
& $(0.00)$ & $(0.00)$ & $(0.00)$ & \\
TangAssets & -0.57 & -0.30 & -0.18 & -0.44 \\
& $(0.00)$ & $(0.00)$ & $(0.07)$ & $(0.00)$ \\
\hline \hline
\end{tabular}

Notes: For definitions of the variables, see notes to Table 3. Correlations are computed across 4-digit SIC industries, with $p$-values reported in parentheses. 
Table 5

Summary statistics: Trade and country-level data

\begin{tabular}{lccccc}
\hline \hline Variable & Obs. & Mean & Std.Dev. & Min & Max \\
\hline Recession alone & 10853303 & 0.14 & 0.34 & 0.00 & 1.00 \\
Fin. Crisis alone & 10853303 & 0.08 & 0.28 & 0.00 & 1.00 \\
Recession \& Fin. Crisis & 10853303 & 0.04 & 0.19 & 0.00 & 1.00 \\
Ln BRER & 10853303 & 4.73 & 0.74 & 1.92 & 7.32 \\
Ln GDP Imp. & 10853303 & 25.75 & 1.98 & 18.46 & 30.23 \\
Ln GDP Exp. & 10853303 & 26.65 & 1.63 & 18.46 & 30.23 \\
FTA & 10853303 & 0.28 & 0.45 & 0.00 & 1.00 \\
Contract Enforcement & 10853303 & 0.66 & 0.47 & 0.00 & 1.00 \\
Ln Distance & 10853303 & 8.27 & 1.04 & 4.09 & 9.89 \\
\hline \hline
\end{tabular}

Notes: $L n$ denotes natural logarithm and the variable names correspond to those employed in the regression analysis. Recession alone, Fin.Crisis alone, and Recession 83 Fin.Crisis are dummy variables at the importingcountry level; BRER is the bilateral real exchange rate; GDP Imp. and GDP Exp. are the real GDP in importing and exporting countries, respectively; FTA denotes free trade agreement (dummy variable); Contract Enforcement is measured by the rule of law; and Distance is the bilateral geographical distance. See text and Appendix Table A1 for further details. 
Table 6

Effects of crises and contractual vulnerability on trade across countries and industries.

Dependent variable: Ln(bilateral sectoral imports)

\begin{tabular}{|c|c|c|c|c|}
\hline & $(1)$ & $(2)$ & $(3)$ & $(4)$ \\
\hline Recession alone & $\begin{array}{r}-0.017^{*} \\
(0.009)\end{array}$ & $\begin{array}{c}-0.016^{*} \\
(0.009)\end{array}$ & $\begin{array}{c}-0.016^{*} \\
(0.009)\end{array}$ & $\begin{array}{c}-0.014 \\
(0.009)\end{array}$ \\
\hline Fin.Crisis alone & $\begin{array}{c}-0.045^{* *} \\
(0.019)\end{array}$ & $\begin{array}{c}-0.044^{* *} \\
(0.019)\end{array}$ & $\begin{array}{c}-0.044^{* *} \\
(0.019)\end{array}$ & $\begin{array}{c}-0.042^{* *} \\
(0.019)\end{array}$ \\
\hline Recession \& Fin.Crisis & $\begin{array}{c}-0.171^{* * *} \\
(0.029)\end{array}$ & $\begin{array}{c}-0.167^{* * * *} \\
(0.029)\end{array}$ & $\begin{array}{c}-0.167^{* * *} \\
(0.029)\end{array}$ & $\begin{array}{c}-0.166^{* * *} \\
(0.029)\end{array}$ \\
\hline Recession alone $\times$ Complexity & & $\begin{array}{c}-0.041^{* * *} \\
(0.014)\end{array}$ & & \\
\hline Fin.Crisis alone $\times$ Complexity & & $\begin{array}{c}-0.079^{* * *} \\
(0.024)\end{array}$ & & \\
\hline Recession \& Fin.Crisis $\times$ Complexity & & $\begin{array}{c}-0.185^{* * *} \\
(0.030)\end{array}$ & & \\
\hline Recession alone $\times$ Concentration & & & $\begin{array}{c}-0.176^{* * *} \\
(0.026)\end{array}$ & \\
\hline Fin. Crisis alone $\times$ Concentration & & & $\begin{array}{c}-0.143^{* * *} \\
(0.045)\end{array}$ & \\
\hline Recession \& Fin.Crisis $\times$ Concentration & & & $\begin{array}{c}-0.338^{* * *} \\
(0.058)\end{array}$ & \\
\hline Recession alone $\times$ Uncollectible & & & & $\begin{array}{c}-0.208^{* * *} \\
(0.038)\end{array}$ \\
\hline Fin.Crisis alone $\times$ Uncollectible & & & & $\begin{array}{l}-0.088 \\
(0.067)\end{array}$ \\
\hline Recession \& Fin.Crisis $\times$ Uncollectible & & & & $\begin{array}{c}-0.308^{* * *} \\
(0.080)\end{array}$ \\
\hline Ln BRER & $\begin{array}{c}-0.229^{* * *} \\
(0.025)\end{array}$ & $\begin{array}{c}-0.229^{* * *} \\
(0.025)\end{array}$ & $\begin{array}{c}-0.229^{* * *} \\
(0.025)\end{array}$ & $\begin{array}{c}-0.232^{* * *} \\
(0.026)\end{array}$ \\
\hline Ln GDP Imp. & $\begin{array}{c}1.143^{* * *} \\
(0.068)\end{array}$ & $\begin{array}{c}1.143^{* * *} \\
(0.068)\end{array}$ & $\begin{array}{c}1.142^{* * *} \\
(0.068)\end{array}$ & $\begin{array}{c}1.128^{* * *} \\
(0.069)\end{array}$ \\
\hline Ln GDP Exp & $\begin{array}{c}1.197^{* * *} \\
(0.039)\end{array}$ & $\begin{array}{c}1.197^{* * *} \\
(0.039)\end{array}$ & $\begin{array}{c}1.198^{* * *} \\
(0.039)\end{array}$ & $\begin{array}{c}1.192^{* * *} \\
(0.041)\end{array}$ \\
\hline FTA & $\begin{array}{c}0.145^{* * *} \\
(0.014)\end{array}$ & $\begin{array}{c}0.145^{* * *} \\
(0.014)\end{array}$ & $\begin{array}{c}0.145^{* * *} \\
(0.014)\end{array}$ & $\begin{array}{c}0.154^{* * *} \\
(0.014)\end{array}$ \\
\hline Observations & $10,853,303$ & $10,853,303$ & $10,853,303$ & $4,132,205$ \\
\hline R-squared & 0.880 & 0.880 & 0.880 & 0.883 \\
\hline Importer-Exporter-Industry FE & YES & YES & YES & YES \\
\hline Year FE & YES & YES & YES & YES \\
\hline Importer-Industry FE 6-year periods & YES & YES & YES & YES \\
\hline Exporter-Industry FE 6-year periods & YES & YES & YES & YES \\
\hline
\end{tabular}

Notes: Standard errors are clustered by destination-year, with ${ }^{* * *},{ }^{* *},{ }^{*}$ denoting significance at the 1\%, 5\% and 10\% levels, respectively. 'Recession' and 'Fin.Crisis' are associated with importing countries. 'Complexity', 'Concentration', and 'Uncollectible' are demeaned. 
Table 7

Amplification effects of contractual vulnerability on industry imports: differential impact of crises $\left(75^{\text {th }}-25^{\text {th }}\right.$ pctl $)$

\begin{tabular}{lccc}
\hline \hline & Recession alone & Fin.Crisis alone & Recession \& Fin.Crisis \\
& $(1)$ & $(2)$ & $(3)$ \\
\hline Complexity & $-0.017^{* * *}$ & $-0.032^{* * *}$ & $-0.075^{* * *}$ \\
& $(0.006)$ & $(0.010)$ & $(0.012)$ \\
Concentration & $-0.019^{* * *}$ & $-0.015^{* * *}$ & $-0.036^{* * *}$ \\
& $(0.003)$ & $(0.005)$ & $(0.006)$ \\
Uncollectible & $-0.028^{* * *}$ & -0.012 & $-0.041^{* * *}$ \\
& $(0.005)$ & $(0.009)$ & $(0.011)$ \\
\hline \hline
\end{tabular}

Notes: The calculations are based on the estimates from Table 6 (columns 2-4), with ${ }^{* * *},{ }^{* *},{ }^{*}$ denoting significance at the $1 \%, 5 \%$ and $10 \%$ levels, respectively. Standard errors are reported in parentheses. For each industry measure of contractual vulnerability, the table shows the differential impact of crises on imports between highly and slightly contract-dependent industries. The calculations assume that a highly (slightly) contract-dependent industry is in the $75^{\text {th }}\left(25^{\text {th }}\right)$ percentile in the distribution of our measures of contractual vulnerability. 


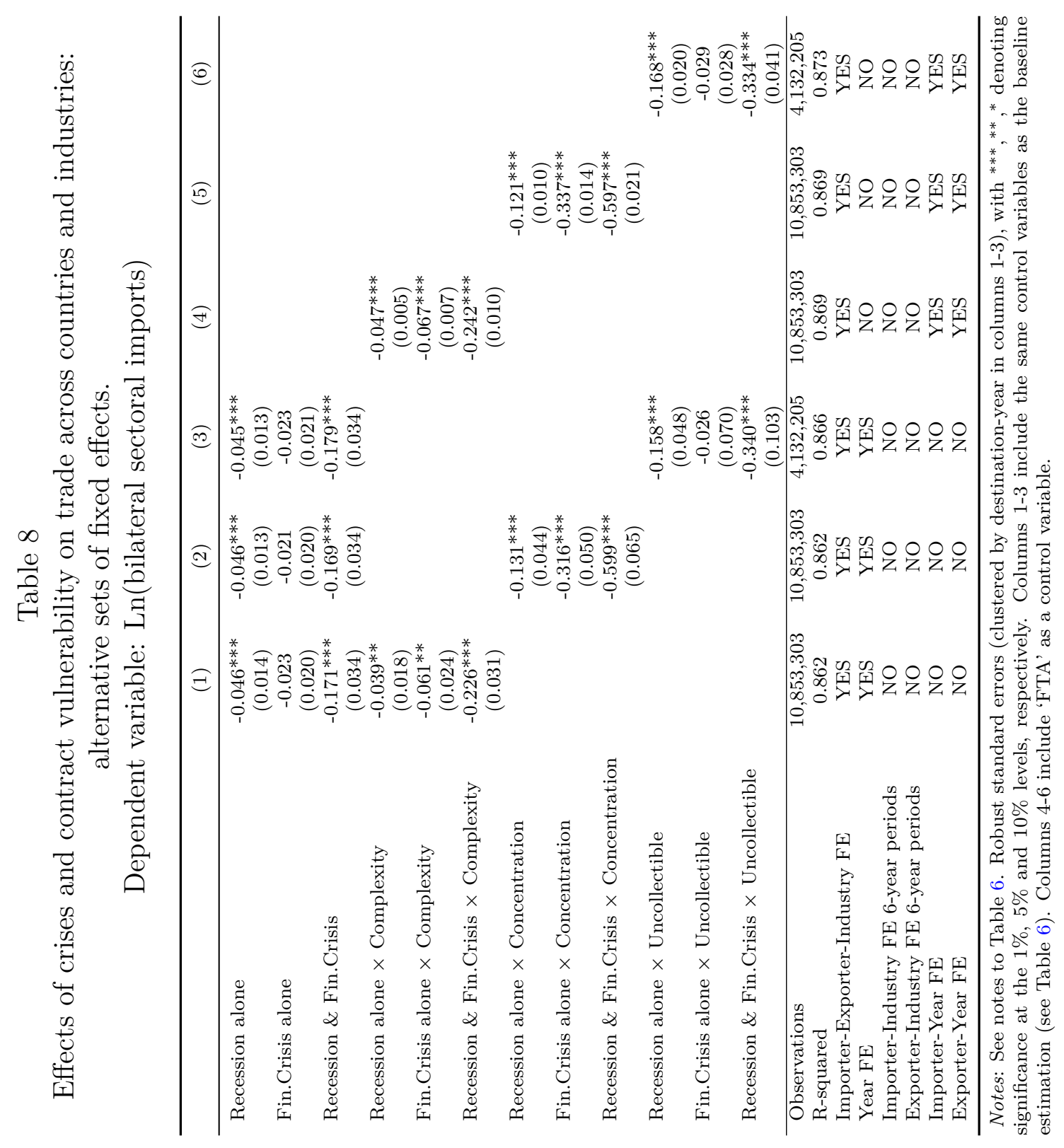


Table 9

Effects of crises and contract vulnerability on trade across countries and industries: controlling for financial vulnerability.

Dependent variable: Ln(bilateral sectoral imports)

\begin{tabular}{|c|c|c|c|}
\hline & (1) & $(2)$ & $(3)$ \\
\hline Recession alone & $\begin{array}{c}-0.015^{*} \\
(0.009)\end{array}$ & $\begin{array}{c}-0.015^{*} \\
(0.009)\end{array}$ & $\begin{array}{l}-0.015 \\
(0.009)\end{array}$ \\
\hline Fin.Crisis alone & $\begin{array}{c}-0.044^{* *} \\
(0.019)\end{array}$ & $\begin{array}{c}-0.044^{* *} \\
(0.019)\end{array}$ & $\begin{array}{c}-0.043^{* *} \\
(0.019)\end{array}$ \\
\hline Recession \& Fin.Crisis & $\begin{array}{c}-0.166^{* * *} \\
(0.029)\end{array}$ & $\begin{array}{c}-0.166^{* * *} \\
(0.029)\end{array}$ & $\begin{array}{c}-0.168^{* * *} \\
(0.029)\end{array}$ \\
\hline Recession alone $\times$ Complexity & $\begin{array}{l}-0.017 \\
(0.013)\end{array}$ & & \\
\hline Fin.Crisis alone $\times$ Complexity & $\begin{array}{c}-0.082^{* * *} \\
(0.024)\end{array}$ & & \\
\hline Recession $\&$ Fin.Crisis $\times$ Complexity & $\begin{array}{c}-0.133^{* * *} \\
(0.028)\end{array}$ & & \\
\hline Recession alone $\times$ Concentration & & $\begin{array}{c}-0.153^{* * *} \\
(0.024)\end{array}$ & \\
\hline Fin.Crisis alone $\times$ Concentration & & $\begin{array}{c}-0.130^{* * *} \\
(0.040)\end{array}$ & \\
\hline Recession $\&$ Fin.Crisis $\times$ Concentration & & $\begin{array}{c}-0.230^{* * *} \\
(0.050)\end{array}$ & \\
\hline Recession alone $\times$ Uncollectible & & & $\begin{array}{c}-0.150^{* * *} \\
(0.036)\end{array}$ \\
\hline Fin.Crisis alone $\times$ Uncollectible & & & $\begin{array}{l}-0.053 \\
(0.059)\end{array}$ \\
\hline Recession \& Fin.Crisis $\times$ Uncollectible & & & $\begin{array}{c}-0.171^{* *} \\
(0.075)\end{array}$ \\
\hline Recession alone $\times$ CashCycle & $\begin{array}{c}-0.033^{* * *} \\
(0.007)\end{array}$ & $\begin{array}{c}-0.021^{* * *} \\
(0.008)\end{array}$ & $\begin{array}{c}-0.041^{* * *} \\
(0.011)\end{array}$ \\
\hline Fin.Crisis alone $\times$ CashCycle & $\begin{array}{c}0.004 \\
(0.012)\end{array}$ & $\begin{array}{c}-0.011 \\
(0.012)\end{array}$ & $\begin{array}{l}-0.025 \\
(0.016)\end{array}$ \\
\hline Recession \& Fin.Crisis $\times$ CashCycle & $\begin{array}{c}-0.070^{* * *} \\
(0.019) \\
\end{array}$ & $\begin{array}{c}-0.093^{* * *} \\
(0.020) \\
\end{array}$ & $\begin{array}{c}-0.098^{* * * *} \\
(0.023) \\
\end{array}$ \\
\hline Observations & $10,853,303$ & $10,853,303$ & $4,132,205$ \\
\hline R-squared & 0.880 & 0.880 & 0.883 \\
\hline Importer-Exporter-Industry FE & YES & YES & YES \\
\hline Year FE & YES & YES & YES \\
\hline Importer-Industry FE 6-year periods & YES & YES & YES \\
\hline Exporter-Industry FE 6-year periods & YES & YES & YES \\
\hline
\end{tabular}

Notes: See notes to Table 6. Standard errors are clustered by destination-year, with ${ }^{* * *},{ }^{* *},{ }^{*}$ denoting significance at the $1 \%, 5 \%$ and $10 \%$ levels, respectively. The regressions include the same control variables as the baseline estimation (see Table 6). 'CashCycle' is demeaned. 
Table 10

Effects of crises and contract vulnerability on trade across countries and industries: controlling for cyclicality.

Dependent variable: Ln(bilateral sectoral imports)

\begin{tabular}{|c|c|c|c|}
\hline & (1) & $(2)$ & $(3)$ \\
\hline Recession alone & $\begin{array}{r}-0.016^{*} \\
(0.009)\end{array}$ & $\begin{array}{r}-0.016^{*} \\
(0.009)\end{array}$ & $\begin{array}{l}-0.014 \\
(0.009)\end{array}$ \\
\hline Fin.Crisis alone & $\begin{array}{c}-0.044^{* *} \\
(0.019)\end{array}$ & $\begin{array}{c}-0.044^{* *} \\
(0.019)\end{array}$ & $\begin{array}{c}-0.042^{* *} \\
(0.019)\end{array}$ \\
\hline Recession \& Fin.Crisis & $\begin{array}{c}-0.167^{* * *} \\
(0.029)\end{array}$ & $\begin{array}{c}-0.167^{* * *} \\
(0.029)\end{array}$ & $\begin{array}{c}-0.166^{* * *} \\
(0.029)\end{array}$ \\
\hline Recession alone $\times$ Complexity & $\begin{array}{c}-0.037^{* * *} \\
(0.014)\end{array}$ & & \\
\hline Fin. Crisis alone $\times$ Complexity & $\begin{array}{c}-0.082^{* * *} \\
(0.024)\end{array}$ & & \\
\hline Recession \& Fin.Crisis $\times$ Complexity & $\begin{array}{c}-0.181^{* * *} \\
(0.031)\end{array}$ & & \\
\hline Recession alone $\times$ Concentration & & $\begin{array}{c}-0.171^{* * *} \\
(0.026)\end{array}$ & \\
\hline Fin. Crisis alone $\times$ Concentration & & $\begin{array}{c}-0.146^{* * *} \\
(0.044)\end{array}$ & \\
\hline Recession \& Fin.Crisis $\times$ Concentration & & $\begin{array}{c}-0.329^{* * *} \\
(0.057)\end{array}$ & \\
\hline Recession alone $\times$ Uncollectible & & & $\begin{array}{c}-0.184^{* * *} \\
(0.038)\end{array}$ \\
\hline Fin.Crisis alone $\times$ Uncollectible & & & $\begin{array}{l}-0.095 \\
(0.066)\end{array}$ \\
\hline Recession \& Fin.Crisis $\times$ Uncollectible & & & $\begin{array}{c}-0.300^{* * *} \\
(0.079)\end{array}$ \\
\hline Recession alone $\times$ Durables (with NX) & $\begin{array}{c}-0.014^{* * *} \\
(0.004)\end{array}$ & $\begin{array}{c}-0.012^{* * *} \\
(0.004)\end{array}$ & $\begin{array}{c}-0.020^{* * *} \\
(0.006)\end{array}$ \\
\hline Fin.Crisis alone $\times$ Durables (with NX) & $\begin{array}{c}0.009 \\
(0.006)\end{array}$ & $\begin{array}{c}0.007 \\
(0.006)\end{array}$ & $\begin{array}{c}0.005 \\
(0.008)\end{array}$ \\
\hline Recession \& Fin.Crisis $\times$ Durables (with NX) & $\begin{array}{r}-0.013^{*} \\
(0.008)\end{array}$ & $\begin{array}{c}-0.018^{* *} \\
(0.007)\end{array}$ & $\begin{array}{l}-0.007 \\
(0.010)\end{array}$ \\
\hline Observations & $10,853,303$ & $10,853,303$ & $4,132,205$ \\
\hline R-squared & 0.880 & 0.880 & 0.883 \\
\hline Importer-Exporter-Product FE & YES & YES & YES \\
\hline Year FE & YES & YES & YES \\
\hline Importer-Industry FE 6-year periods & YES & YES & YES \\
\hline Exporter-Industry FE 6-year periods & YES & YES & YES \\
\hline
\end{tabular}

Notes: See notes to Table 6. Standard errors are clustered by destination-year, with ***,**,* denoting significance at the $1 \%, 5 \%$ and $10 \%$ levels, respectively. The regressions include the same control variables as the baseline estimation (see Table 6). 
Table 11

Effects of crises and contract vulnerability on trade across countries and industries: controlling for upstreamness.

Dependent variable: Ln(bilateral sectoral imports)

\begin{tabular}{|c|c|c|c|}
\hline & $(1)$ & $(2)$ & $(3)$ \\
\hline Recession alone & $\begin{array}{c}-0.015^{*} \\
(0.009)\end{array}$ & $\begin{array}{c}-0.015^{*} \\
(0.009)\end{array}$ & $\begin{array}{c}-0.014 \\
(0.009)\end{array}$ \\
\hline Fin.Crisis alone & $\begin{array}{c}-0.044^{* *} \\
(0.019)\end{array}$ & $\begin{array}{c}-0.044^{* *} \\
(0.019)\end{array}$ & $\begin{array}{c}-0.043^{* *} \\
(0.019)\end{array}$ \\
\hline Recession \& Fin.Crisis & $\begin{array}{c}-0.166^{* * *} \\
(0.029)\end{array}$ & $\begin{array}{c}-0.167^{* * *} \\
(0.029)\end{array}$ & $\begin{array}{c}-0.166^{* * *} \\
(0.029)\end{array}$ \\
\hline Recession alone $\times$ Complexity & $\begin{array}{c}-0.066^{* * *} \\
(0.014)\end{array}$ & & \\
\hline Fin.Crisis alone $\times$ Complexity & $\begin{array}{c}-0.080^{* * *} \\
(0.025)\end{array}$ & & \\
\hline Recession \& Fin.Crisis $\times$ Complexity & $\begin{array}{c}-0.204^{* * *} \\
(0.032)\end{array}$ & & \\
\hline Recession alone $\times$ Concentration & & $\begin{array}{c}-0.185^{* * *} \\
(0.027)\end{array}$ & \\
\hline Fin.Crisis alone $\times$ Concentration & & $\begin{array}{c}-0.142^{* * *} \\
(0.045)\end{array}$ & \\
\hline Recession \& Fin.Crisis $\times$ Concentration & & $\begin{array}{c}-0.340^{* * *} \\
(0.058)\end{array}$ & \\
\hline Recession alone $\times$ Uncollectible & & & $\begin{array}{c}-0.211^{* * *} \\
(0.038)\end{array}$ \\
\hline Fin.Crisis alone $\times$ Uncollectible & & & $\begin{array}{l}-0.083 \\
(0.067)\end{array}$ \\
\hline Recession \& Fin.Crisis $\times$ Uncollectible & & & $\begin{array}{c}-0.306^{* * *} \\
(0.081)\end{array}$ \\
\hline Recession alone $\times$ Upstreamness & $\begin{array}{c}-0.123^{* * *} \\
(0.016)\end{array}$ & $\begin{array}{c}-0.108^{* * *} \\
(0.015)\end{array}$ & $\begin{array}{c}-0.091^{* * *} \\
(0.017)\end{array}$ \\
\hline Fin.Crisis alone $\times$ Upstreamness & $\begin{array}{c}-0.001 \\
(0.033)\end{array}$ & $\begin{array}{c}0.020 \\
(0.032)\end{array}$ & $\begin{array}{l}0.055^{*} \\
(0.032)\end{array}$ \\
\hline Recession \& Fin.Crisis $\times$ Upstreamness & $\begin{array}{c}-0.088^{* *} \\
(0.041)\end{array}$ & $\begin{array}{c}-0.033 \\
(0.040)\end{array}$ & $\begin{array}{c}0.026 \\
(0.039)\end{array}$ \\
\hline Observations & $10,853,303$ & $10,853,303$ & $4,132,205$ \\
\hline R-squared & 0.880 & 0.880 & 0.883 \\
\hline Importer-Exporter-Product FE & YES & YES & YES \\
\hline Year FE & YES & YES & YES \\
\hline Importer-Industry FE 6-year periods & YES & YES & YES \\
\hline Exporter-Industry FE 6-year periods & YES & YES & YES \\
\hline
\end{tabular}

Notes: See notes to Table 6. Standard errors are clustered by destination-year, with ${ }^{* * *},{ }^{* *},{ }^{*}$ denoting significance at the $1 \%, 5 \%$ and $10 \%$ levels, respectively. The regressions include the same control variables as the baseline estimation (see Table 6). 'Upstreamness' is demeaned. 
Table 12

Effects of crises and contract vulnerability on trade across countries and industries: controlling for product differentiation.

Dependent variable: Ln(bilateral sectoral imports)

\begin{tabular}{|c|c|c|c|}
\hline & (1) & $(2)$ & $(3)$ \\
\hline Recession alone & $\begin{array}{c}-0.016^{*} \\
(0.009)\end{array}$ & $\begin{array}{c}-0.016^{*} \\
(0.009)\end{array}$ & $\begin{array}{c}-0.014 \\
(0.009)\end{array}$ \\
\hline Fin.Crisis alone & $\begin{array}{c}-0.044^{* *} \\
(0.019)\end{array}$ & $\begin{array}{c}-0.044^{* *} \\
(0.019)\end{array}$ & $\begin{array}{c}-0.044^{* *} \\
(0.019)\end{array}$ \\
\hline Recession \& Fin.Crisis & $\begin{array}{c}-0.167^{* * *} \\
(0.029)\end{array}$ & $\begin{array}{c}-0.168^{* * *} \\
(0.029)\end{array}$ & $\begin{array}{c}-0.167^{* * *} \\
(0.029)\end{array}$ \\
\hline Recession alone $\times$ Complexity & $\begin{array}{c}-0.042^{* * *} \\
(0.013)\end{array}$ & & \\
\hline Fin.Crisis alone $\times$ Complexity & $\begin{array}{c}-0.064^{* * *} \\
(0.020)\end{array}$ & & \\
\hline Recession \& Fin.Crisis $\times$ Complexity & $\begin{array}{c}-0.167^{* * *} \\
(0.029)\end{array}$ & & \\
\hline Recession alone $\times$ Concentration & & $\begin{array}{c}-0.200^{* * *} \\
(0.025)\end{array}$ & \\
\hline Fin.Crisis alone $\times$ Concentration & & $\begin{array}{c}-0.098^{* *} \\
(0.041)\end{array}$ & \\
\hline Recession \& Fin.Crisis $\times$ Concentration & & $\begin{array}{c}-0.264^{* * *} \\
(0.058)\end{array}$ & \\
\hline Recession alone $\times$ Uncollectible & & & $\begin{array}{c}-0.190^{* * *} \\
(0.035)\end{array}$ \\
\hline Fin.Crisis alone $\times$ Uncollectible & & & $\begin{array}{l}-0.016 \\
(0.063)\end{array}$ \\
\hline Recession \& Fin.Crisis $\times$ Uncollectible & & & $\begin{array}{c}-0.223^{* * *} \\
(0.077)\end{array}$ \\
\hline Recession alone $\times$ Differentiation & $\begin{array}{c}0.001 \\
(0.006)\end{array}$ & $\begin{array}{l}0.013^{*} \\
(0.007)\end{array}$ & $\begin{array}{l}-0.010 \\
(0.008)\end{array}$ \\
\hline Fin.Crisis alone $\times$ Differentiation & $\begin{array}{l}-0.016 \\
(0.011)\end{array}$ & $\begin{array}{c}-0.025^{*} \\
(0.013)\end{array}$ & $\begin{array}{c}-0.040^{* * *} \\
(0.013)\end{array}$ \\
\hline Recession \& Fin.Crisis $\times$ Differentiation & $\begin{array}{l}-0.018 \\
(0.014)\end{array}$ & $\begin{array}{c}-0.040^{* *} \\
(0.016)\end{array}$ & $\begin{array}{c}-0.047^{* * * *} \\
(0.016)\end{array}$ \\
\hline Observations & $10,853,303$ & $10,853,303$ & $4,132,205$ \\
\hline R-squared & 0.880 & 0.880 & 0.883 \\
\hline Importer-Exporter-Product FE & YES & YES & YES \\
\hline Year FE & YES & YES & YES \\
\hline Importer-Industry FE 6-year periods & YES & YES & YES \\
\hline Exporter-Industry FE 6-year periods & YES & YES & YES \\
\hline
\end{tabular}

Notes: See notes to Table 6. Standard errors are clustered by destination-year, with ${ }^{* * *},{ }^{* *},{ }^{*}$ denoting significance at the $1 \%, 5 \%$ and $10 \%$ levels, respectively. The regressions include the same control variables as the baseline estimation (see Table 6). 
Table 13

Effects of crises and contract vulnerability on trade across countries and industries: controlling for financial vulnerability, cyclicality, upstreamness, and differentiation. Dependent variable: Ln(bilateral sectoral imports)

\begin{tabular}{|c|c|c|c|}
\hline & (1) & $(2)$ & (3) \\
\hline Recession alone & $\begin{array}{l}-0.015 \\
(0.009)\end{array}$ & $\begin{array}{l}-0.015 \\
(0.009)\end{array}$ & $\begin{array}{c}-0.016^{*} \\
(0.009)\end{array}$ \\
\hline Fin.Crisis alone & $\begin{array}{c}-0.044^{* *} \\
(0.019)\end{array}$ & $\begin{array}{c}-0.044^{* *} \\
(0.019)\end{array}$ & $\begin{array}{c}-0.044^{* *} \\
(0.019)\end{array}$ \\
\hline Recession \& Fin.Crisis & $\begin{array}{c}-0.165^{* * *} \\
(0.029)\end{array}$ & $\begin{array}{c}-0.165^{* * *} \\
(0.029)\end{array}$ & $\begin{array}{c}-0.169^{* * *} \\
(0.029)\end{array}$ \\
\hline Recession alone $\times$ Complexity & $\begin{array}{c}-0.038^{* * *} \\
(0.013)\end{array}$ & & \\
\hline Fin.Crisis alone $\times$ Complexity & $\begin{array}{c}-0.070^{* * *} \\
(0.021)\end{array}$ & & \\
\hline Recession \& Fin.Crisis $\times$ Complexity & $\begin{array}{c}-0.138^{* * *} \\
(0.027)\end{array}$ & & \\
\hline Recession alone $\times$ Concentration & & $\begin{array}{c}-0.153^{* * *} \\
(0.024)\end{array}$ & \\
\hline Fin. Crisis alone $\times$ Concentration & & $\begin{array}{c}-0.097^{* * *} \\
(0.036)\end{array}$ & \\
\hline Recession \& Fin.Crisis $\times$ Concentration & & $\begin{array}{c}-0.186^{* * *} \\
(0.050)\end{array}$ & \\
\hline Recession alone $\times$ Uncollectible & & & $\begin{array}{c}-0.098^{* * *} \\
(0.035)\end{array}$ \\
\hline Fin.Crisis alone $\times$ Uncollectible & & & $\begin{array}{l}-0.026 \\
(0.057)\end{array}$ \\
\hline Recession \& Fin.Crisis $\times$ Uncollectible & & & $\begin{array}{c}-0.146^{* *} \\
(0.070)\end{array}$ \\
\hline Recession alone $\times$ CashCycle & $\begin{array}{c}-0.017^{* * *} \\
(0.007)\end{array}$ & $\begin{array}{c}-0.018^{* *} \\
(0.007)\end{array}$ & $\begin{array}{c}-0.028^{* * *} \\
(0.010)\end{array}$ \\
\hline Fin. Crisis alone $\times$ CashCycle & $\begin{array}{c}0.005 \\
(0.011)\end{array}$ & $\begin{array}{l}-0.007 \\
(0.011)\end{array}$ & $\begin{array}{l}-0.009 \\
(0.016)\end{array}$ \\
\hline Recession \& Fin.Crisis $\times$ CashCycle & $\begin{array}{l}-0.056^{* * *} \\
(0.018)\end{array}$ & $\begin{array}{c}-0.081^{* * *} \\
(0.019)\end{array}$ & $\begin{array}{c}-0.088^{* * *} \\
(0.026)\end{array}$ \\
\hline Recession alone $\times$ Durables (with NX) & $\begin{array}{c}-0.011^{* * *} \\
(0.004)\end{array}$ & $\begin{array}{c}-0.011^{* * *} \\
(0.004)\end{array}$ & $\begin{array}{c}-0.017^{* * *} \\
(0.006)\end{array}$ \\
\hline Fin.Crisis alone $\times$ Durables (with NX) & $\begin{array}{c}0.009 \\
(0.006)\end{array}$ & $\begin{array}{c}0.009 \\
(0.006)\end{array}$ & $\begin{array}{c}0.008 \\
(0.009)\end{array}$ \\
\hline Recession \& Fin.Crisis $\times$ Durables (with NX) & $\begin{array}{l}-0.006 \\
(0.008)\end{array}$ & $\begin{array}{l}-0.007 \\
(0.008)\end{array}$ & $\begin{array}{c}0.007 \\
(0.011)\end{array}$ \\
\hline Recession alone $\times$ Upstreamness & $\begin{array}{c}-0.126^{* * *} \\
(0.016)\end{array}$ & $\begin{array}{c}-0.111^{* * *} \\
(0.015)\end{array}$ & $\begin{array}{c}-0.124^{* * *} \\
(0.018)\end{array}$ \\
\hline Fin.Crisis alone $\times$ Upstreamness & $\begin{array}{l}-0.010 \\
(0.032)\end{array}$ & $\begin{array}{c}0.005 \\
(0.031)\end{array}$ & $\begin{array}{c}0.027 \\
(0.034)\end{array}$ \\
\hline Recession \& Fin.Crisis $\times$ Upstreamness & $\begin{array}{c}-0.087^{* *} \\
(0.040)\end{array}$ & $\begin{array}{l}-0.057 \\
(0.039)\end{array}$ & $\begin{array}{c}-0.011 \\
(0.043)\end{array}$ \\
\hline Recession alone $\times$ Differentiation & $\begin{array}{c}-0.014^{* *} \\
(0.006)\end{array}$ & $\begin{array}{c}-0.004 \\
(0.006)\end{array}$ & $\begin{array}{c}-0.030^{* * * *} \\
(0.008)\end{array}$ \\
\hline Fin. Crisis alone $\times$ Differentiation & $\begin{array}{c}-0.018^{*} \\
(0.010)\end{array}$ & $\begin{array}{c}-0.023^{* *} \\
(0.011)\end{array}$ & $\begin{array}{c}-0.031^{* *} \\
(0.014)\end{array}$ \\
\hline Recession \& Fin.Crisis $\times$ Differentiation & $\begin{array}{c}-0.023^{*} \\
(0.013)\end{array}$ & $\begin{array}{c}-0.031^{* *} \\
(0.014)\end{array}$ & $\begin{array}{c}-0.026 \\
(0.018)\end{array}$ \\
\hline Observations & $10,853,303$ & $10,853,303$ & $4,132,205$ \\
\hline R-squared & 0.880 & 0.880 & 0.883 \\
\hline Importer-Exporter-Product FE & YES & YES & YES \\
\hline Year FE & YES & YES & YES \\
\hline Importer-Industry FE 6-year periods & YES & YES & YES \\
\hline Exporter-Industry FE 6-year periods & YES & YES & YES \\
\hline
\end{tabular}

Notes: See notes to Table 6. Standard errors are clustered by destination-year, with ***,**,* denoting significance at the $1 \%, 5 \%$ and $10 \%$ levels, respectively. The regressions include the same control variables as the baseline estimation (see Table 6). 'CashCycle' and 'Upstreamness' are demeaned. 


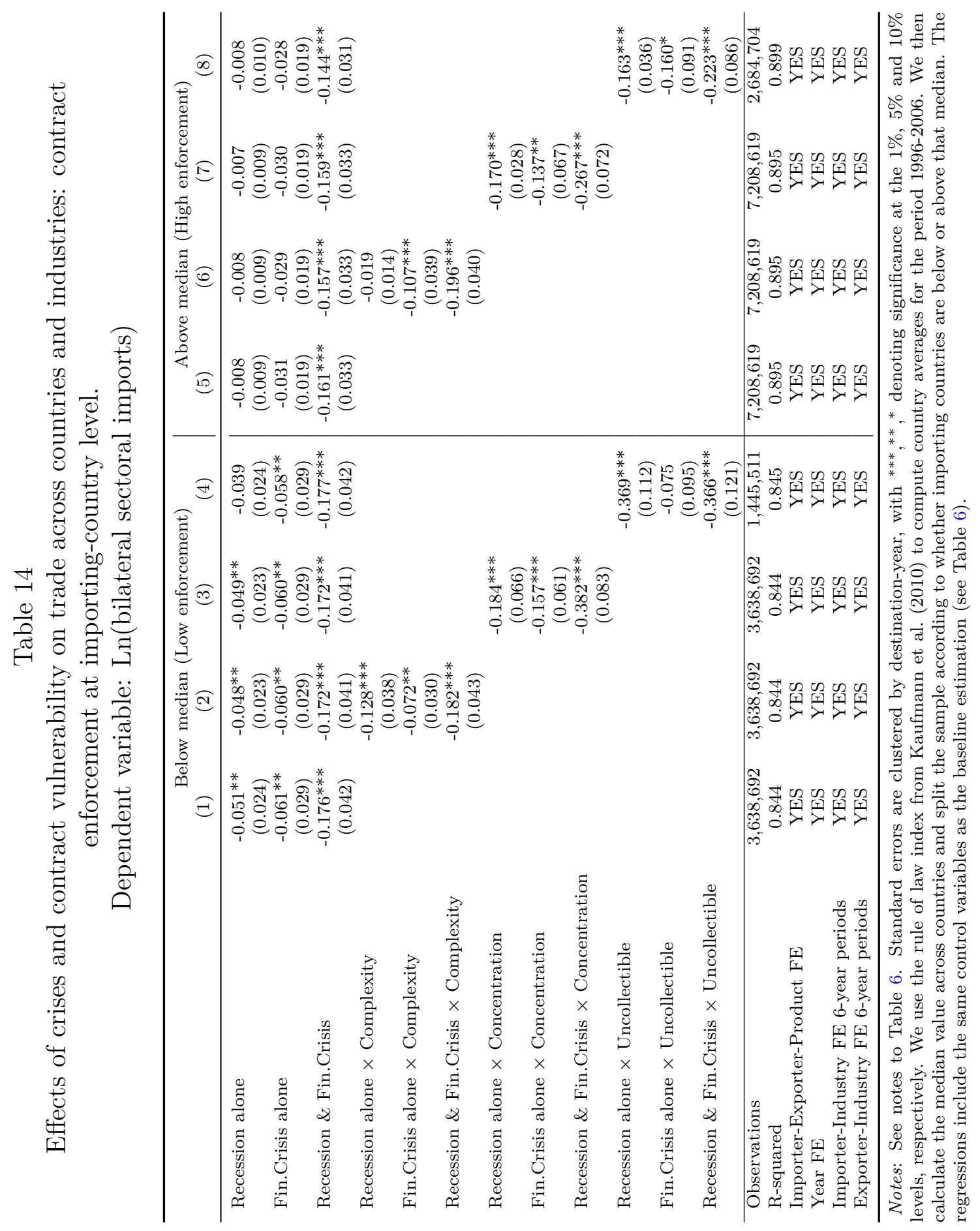


Table 15

Effects of crises and contract vulnerability on trade across countries and industries: the role of distance.

Dependent variable: Ln(bilateral sectoral imports)

\begin{tabular}{|c|c|c|c|}
\hline & $(1)$ & $(2)$ & $(3)$ \\
\hline Recession alone & $\begin{array}{r}-0.017^{*} \\
(0.009)\end{array}$ & $\begin{array}{r}-0.017^{*} \\
(0.009)\end{array}$ & $\begin{array}{l}-0.015 \\
(0.009)\end{array}$ \\
\hline Fin.Crisis alone & $\begin{array}{c}-0.046^{* *} \\
(0.019)\end{array}$ & $\begin{array}{c}-0.047^{* *} \\
(0.019)\end{array}$ & $\begin{array}{c}-0.046^{* *} \\
(0.019)\end{array}$ \\
\hline Recession \& Fin.Crisis & $\begin{array}{c}-0.172^{* * *} \\
(0.030)\end{array}$ & $\begin{array}{c}-0.173^{* * *} \\
(0.030)\end{array}$ & $\begin{array}{c}-0.173^{* * *} \\
(0.031)\end{array}$ \\
\hline Recession alone $\times$ Complexity & $\begin{array}{c}-0.040 * * * \\
(0.014)\end{array}$ & & \\
\hline Fin. Crisis alone $\times$ Complexity & $\begin{array}{c}-0.073^{* * *} \\
(0.024)\end{array}$ & & \\
\hline Recession \& Fin.Crisis $\times$ Complexity & $\begin{array}{c}-0.165^{* * *} \\
(0.029)\end{array}$ & & \\
\hline Recession alone $\times$ Concentration & & $\begin{array}{l}-0.174^{* * *} \\
(0.027)\end{array}$ & \\
\hline Fin. Crisis alone $\times$ Concentration & & $\begin{array}{c}-0.144^{* * *} \\
(0.044)\end{array}$ & \\
\hline Recession \& Fin.Crisis $\times$ Concentration & & $\begin{array}{c}-0.315^{* * *} \\
(0.056)\end{array}$ & \\
\hline Recession alone $\times$ Uncollectible & & & $\begin{array}{c}-0.205^{* * *} \\
(0.038)\end{array}$ \\
\hline Fin.Crisis alone $\times$ Uncollectible & & & $\begin{array}{l}-0.074 \\
(0.067)\end{array}$ \\
\hline Recession \& Fin.Crisis $\times$ Uncollectible & & & $\begin{array}{c}-0.276^{* * *} \\
(0.083)\end{array}$ \\
\hline Recession alone $\times$ Complexity $\times$ Distance & $\begin{array}{c}-0.030^{* * *} \\
(0.009)\end{array}$ & & \\
\hline Fin.Crisis alone $\times$ Complexity $\times$ Distance & $\begin{array}{c}-0.079 * * * \\
(0.017)\end{array}$ & & \\
\hline Recession $\&$ Fin.Crisis $\times$ Complexity $\times$ Distance & $\begin{array}{l}-0.124^{* * *} \\
(0.027)\end{array}$ & & \\
\hline Recession alone $\times$ Concentration $\times$ Distance & & $\begin{array}{l}-0.015 \\
(0.018)\end{array}$ & \\
\hline Fin. Crisis alone $\times$ Concentration $\times$ Distance & & $\begin{array}{c}-0.063^{* *} \\
(0.028)\end{array}$ & \\
\hline Recession $\&$ Fin. Crisis $\times$ Concentration $\times$ Distance & & $\begin{array}{c}-0.173^{* * *} \\
(0.048)\end{array}$ & \\
\hline Recession alone $\times$ Uncollectible $\times$ Distance & & & $\begin{array}{l}-0.030 \\
(0.030)\end{array}$ \\
\hline Fin.Crisis alone $\times$ Uncollectible $\times$ Distance & & & $\begin{array}{c}-0.130^{* * *} \\
(0.049)\end{array}$ \\
\hline Recession \& Fin.Crisis $\times$ Uncollectible $\times$ Distance & & & $\begin{array}{c}-0.194^{* *} \\
(0.078) \\
\end{array}$ \\
\hline Observations & $10,853,303$ & $10,853,303$ & $4,132,205$ \\
\hline R-squared & 0.880 & 0.880 & 0.883 \\
\hline Importer-Exporter-Product FE & YES & YES & YES \\
\hline Year FE & YES & YES & YES \\
\hline Importer-Industry FE 6-year periods & YES & YES & YES \\
\hline Exporter-Industry FE 6-year periods & YES & YES & YES \\
\hline
\end{tabular}

Notes: See notes to Table 6. Robust standard errors (clustered by destination-year), with ***, ${ }^{* *},{ }^{*}$ denoting significance at the $1 \%, 5 \%$ and $10 \%$ levels, respectively. The regressions include the same control variables as the baseline estimation (see Table 6), and also the interaction terms 'Recession alone $\times$ Distance', 'Fin.Crisis alone $\times$ Distance', and 'Recession $\&$ Fin.Crisis $\times$ Distance' (not reported to save space). 'Distance' is demeaned. 
Figure 1

Share of observations with crises, by year

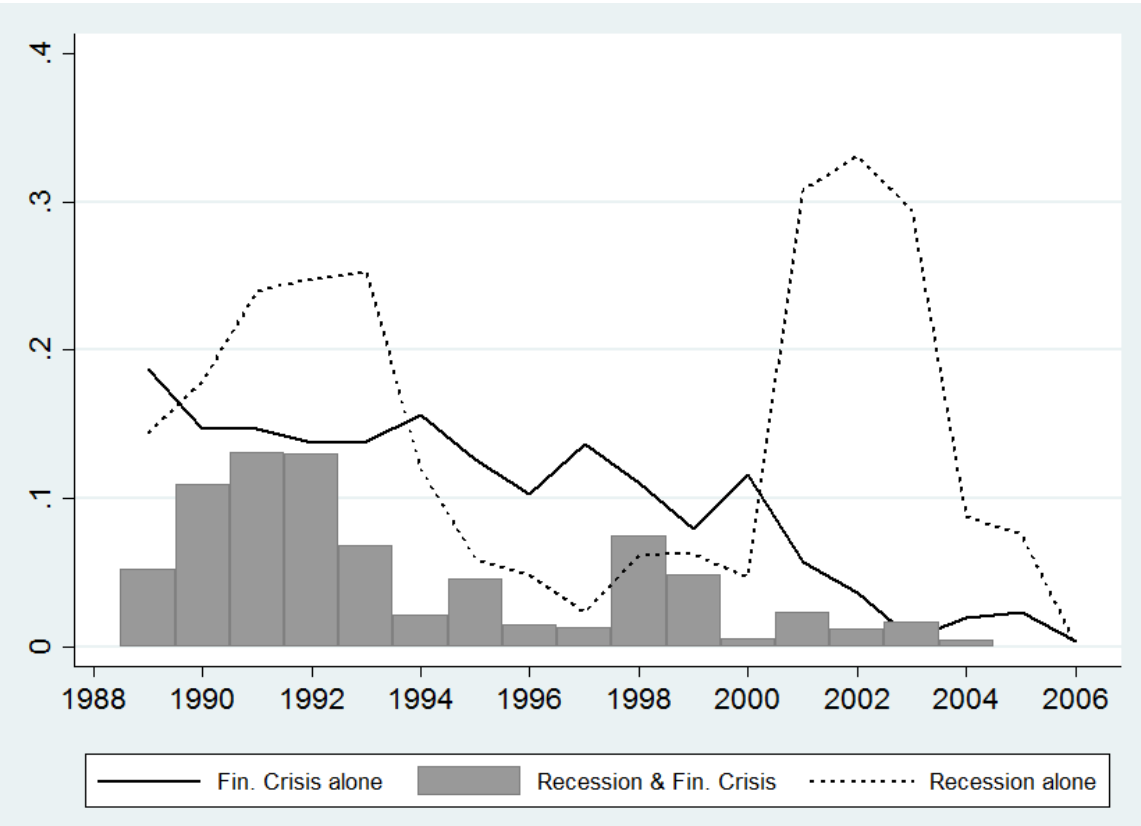

Notes: Recessions are identified using the Braun and Larrain (2005) methodology. Financial crises are identified as banking or sovereign debt crises, using the Laeven and Valencia (2013) dataset. 
Figure 2

Distribution of the uncollectible index

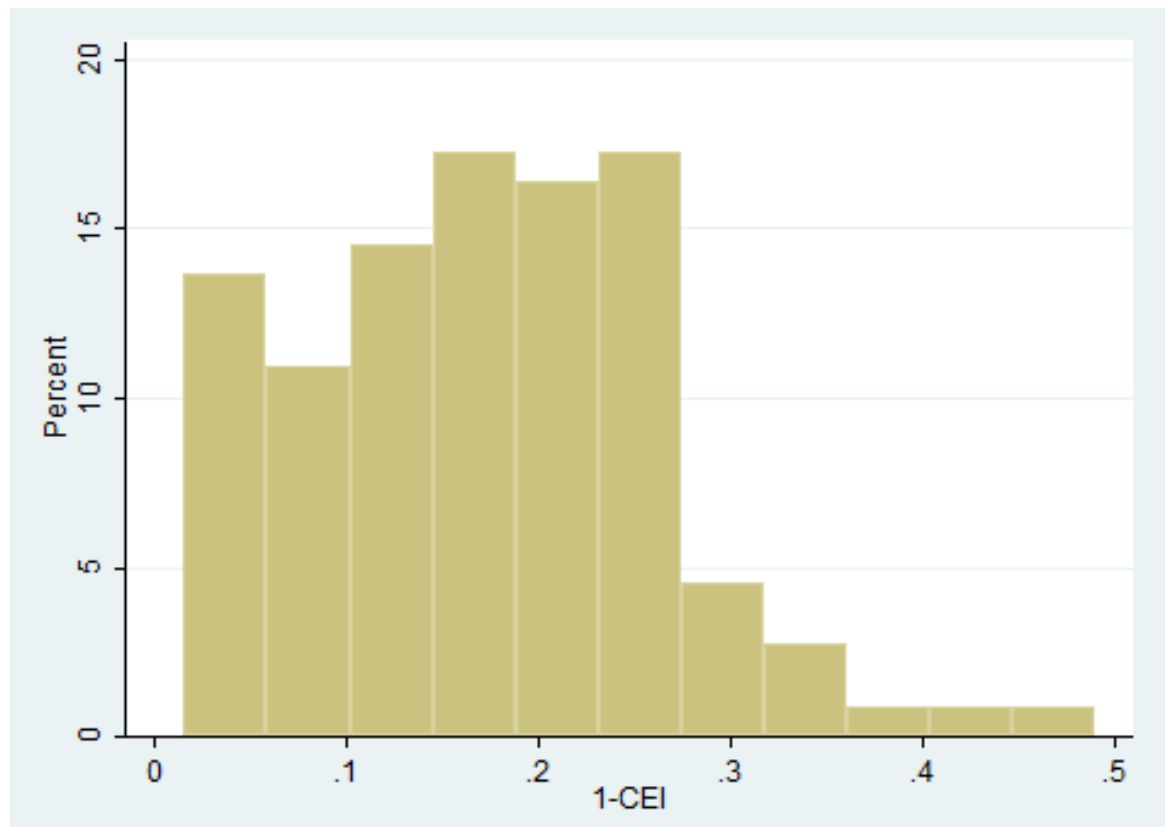

Notes: The bars represent the histogram of the uncollectible index. The uncollectible index is constructed as $1-C E I$, where $C E I$ is the Collection Effectiveness Index reported in the Credit Research Foundation's National Summary of Domestic Trade Receivables. We calculate (4-digit SIC) industry medians over the period 2006q1-2010q4, and divide them by 100 to express them as decimals. 
Figure 3

Distribution of complexity index and concentration index, by cyclicality of industries

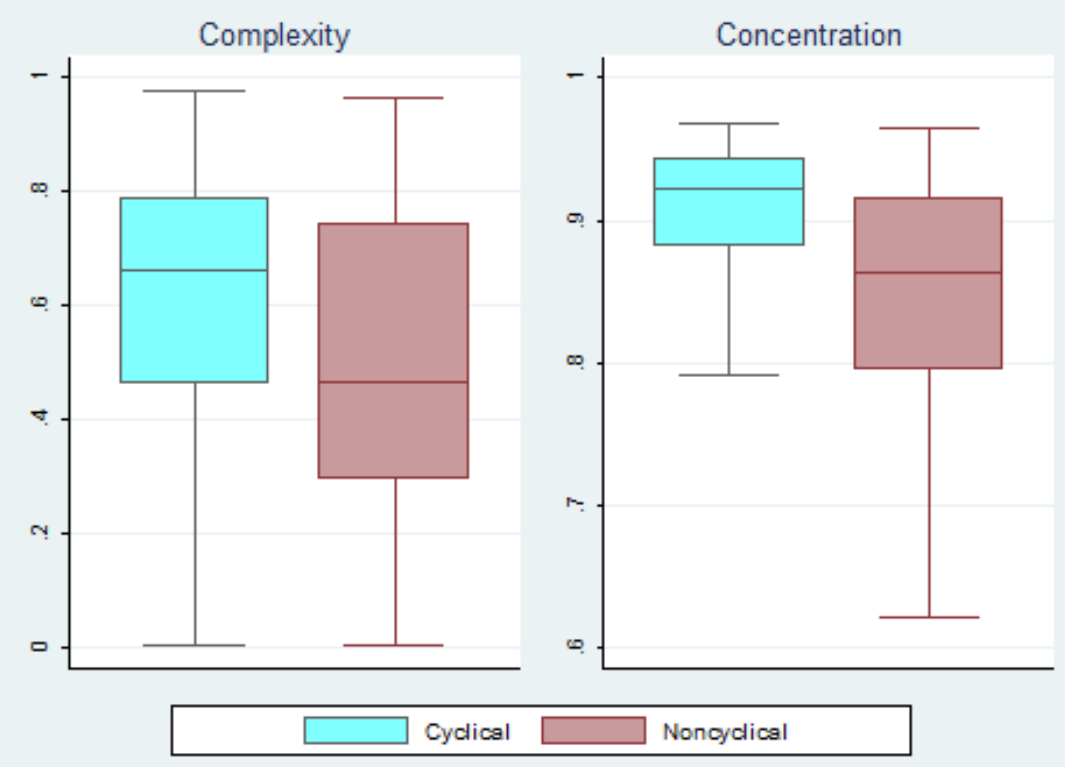

Notes: The box-and-whisker plots show the interquartile range, the median, and the most extreme values that are within $3 / 2$ times the interquartile range of the 1st and 3rd quartiles. Complexity is the input relationship-specificity index from Nunn (2007). Concentration is the input concentration index from Levchenko (2007). Based on Gomes et al's (2009) classification of 4-digit SIC industries by final demand, our cyclical industries include durable consumption and investment goods; noncyclical industries include nondurable consumption, government consumption and investment, consumption of services, and net exports of goods and services. 


\title{
Appendix
}

\section{A Data sources}

\author{
Table A1
}

Data sources

\begin{tabular}{lr}
\hline \multicolumn{1}{c}{ Variable } & Trade and country-level data \\
World export and import data & Cource \\
US export data & Center for International Data and Comtrade database \\
World export price index & Center for International Data \\
Real GDP in US Dollars & IFS database \\
Bilateral real exchange rate & WDI database \\
Free trade agreements & Penn World Table 8.1 \\
Bilateral geographic distance & de Sousa (2012) \\
Rule of law & CEPII distance database \\
Contract viability & Worldwide Governance Indicators database \\
Payment delay & International Country Risk Guide \\
Banking crisis dates & International Country Risk Guide \\
Sovereign debt crisis dates & Laeven and Valencia (2013) \\
\hline \multicolumn{1}{c}{ Variable } & Laeven and Valencia (2013) \\
\hline Complexity index & Source \\
Concentration index & Chdustry data \\
Collection Effectiveness Index & Chor (2010) (based on Nunn, 2007) \\
Cash conversion cycle & Chor (2010) (based on Levchenko, 2007) \\
Asset tangibility & Credit Research Foundation \\
Cyclicality & Compustat \\
Upstreamness & Compustat (based on Braun, 2003) \\
Differentiation & Durability classification by Gomes et al. (2009) \\
\hline \hline
\end{tabular}




\section{B Data from the National Summary of Domestic Trade Receivables}

The National Summary of Domestic Trade Receivables (NSDTR) data are in readable PDF format, so we first transcribe these files to machine-readable format. The NSDTR's Collection Effectiveness Index (CEI) is constructed as follows:

$\mathrm{CEI}=\frac{\text { Beginning total receiv. }+(\text { Quarterly credit sales } / 3)-\text { Ending total receiv. }}{\text { Beginning total receiv. }+(\text { Quarterly credit sales } / 3)-\text { Ending current receiv. }}$ where:

'Beginning (Ending) total receiv.': Receivables balance at beginning (end) of 3-month period being reported. Considers all domestic open invoices and notes receivable, deferred billings or datings, past-due billings, credits, unapplied cash, suspense accounts, charge backs, invoice deductions, bankruptcies, claims, disputes, litigation and accounts placed for collections.

'Quarterly credit sales': Total invoiced receivable for the 3-month period reported. Includes freight, taxes, and containers.

'Ending current receiv.: Portion of receivables (domestic open accounts and notes) not yet due as of end of period according to terms, including datings and deferred items.

We take median values across quarters by 4-digit SIC industry. On each quarter, the survey includes only industries that report a minimum of 3 responding firms. For more detailed information about the NSDTR, see http://www . crfonline.org/surveys/ surveys.asp.

Table A2 summarizes the 10 most and 10 least collection-effective industries. 


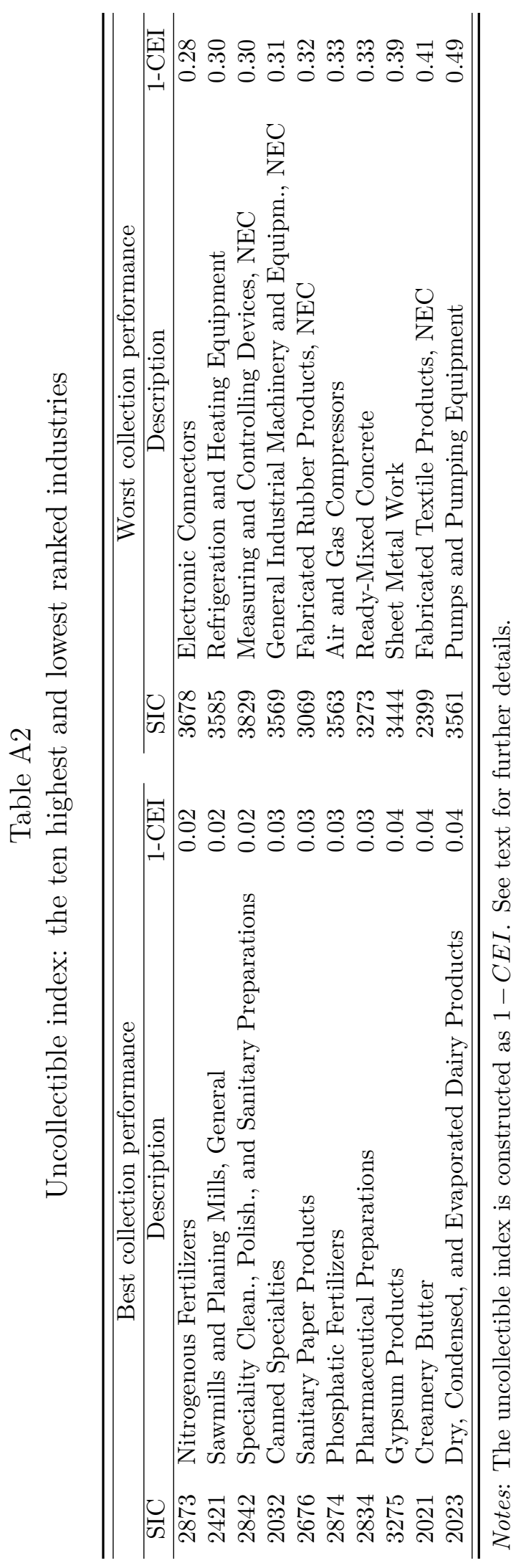




\title{
C Sensitivity analysis: additional results
}

\author{
Table A3
}

Effects of crises and contract vulnerability on trade across countries and industries: controlling for financial vulnerability.

Dependent variable: Ln(bilateral sectoral imports)

\begin{tabular}{|c|c|c|c|}
\hline & $(1)$ & $(2)$ & $(3)$ \\
\hline Recession alone & $\begin{array}{l}-0.016^{*} \\
(0.009)\end{array}$ & $\begin{array}{r}-0.016^{*} \\
(0.009)\end{array}$ & $\begin{array}{l}-0.014 \\
(0.009)\end{array}$ \\
\hline Fin.Crisis alone & $\begin{array}{c}-0.044^{* *} \\
(0.019)\end{array}$ & $\begin{array}{c}-0.044^{* *} \\
(0.019)\end{array}$ & $\begin{array}{c}-0.042^{* *} \\
(0.019)\end{array}$ \\
\hline Recession \& Fin.Crisis & $\begin{array}{c}-0.167^{* * *} \\
(0.029)\end{array}$ & $\begin{array}{c}-0.167^{* * *} \\
(0.029)\end{array}$ & $\begin{array}{c}-0.165^{* * *} \\
(0.029)\end{array}$ \\
\hline Recession alone $\times$ Complexity & $\begin{array}{c}-0.056^{* * *} \\
(0.012)\end{array}$ & & \\
\hline Fin.Crisis alone $\times$ Complexity & $\begin{array}{c}-0.073^{* * *} \\
(0.021)\end{array}$ & & \\
\hline Recession \& Fin.Crisis $\times$ Complexity & $\begin{array}{c}-0.180^{* * *} \\
(0.027)\end{array}$ & & \\
\hline Recession alone $\times$ Concentration & & $\begin{array}{c}-0.189^{* * *} \\
(0.024)\end{array}$ & \\
\hline Fin.Crisis alone $\times$ Concentration & & $\begin{array}{c}-0.117^{* * *} \\
(0.041)\end{array}$ & \\
\hline Recession \& Fin.Crisis $\times$ Concentration & & $\begin{array}{c}-0.286^{* * *} \\
(0.052)\end{array}$ & \\
\hline Recession alone $\times$ Uncollectible & & & $\begin{array}{c}-0.204^{* * *} \\
(0.037)\end{array}$ \\
\hline Fin.Crisis alone $\times$ Uncollectible & & & $\begin{array}{l}-0.061 \\
(0.065)\end{array}$ \\
\hline Recession \& Fin.Crisis $\times$ Uncollectible & & & $\begin{array}{c}-0.265^{* * *} \\
(0.080)\end{array}$ \\
\hline Recession alone $\times$ TangAssets & $\begin{array}{c}-0.041^{* * *} \\
(0.014)\end{array}$ & $\begin{array}{l}-0.029^{*} \\
(0.018)\end{array}$ & $\begin{array}{c}0.015 \\
(0.026)\end{array}$ \\
\hline Fin.Crisis alone $\times$ TangAssets & $\begin{array}{c}0.016 \\
(0.021)\end{array}$ & $\begin{array}{c}0.060^{* *} \\
(0.028)\end{array}$ & $\begin{array}{c}0.101^{* * *} \\
(0.036)\end{array}$ \\
\hline Recession \& Fin.Crisis $\times$ TangAssets & $\begin{array}{c}0.012 \\
(0.030) \\
\end{array}$ & $\begin{array}{c}0.118^{* * *} \\
(0.037) \\
\end{array}$ & $\begin{array}{c}0.160^{* * *} \\
(0.051)\end{array}$ \\
\hline Observations & $10,853,303$ & $10,853,303$ & $4,132,205$ \\
\hline R-squared & 0.880 & 0.880 & 0.883 \\
\hline Importer-Exporter-Industry FE & YES & YES & YES \\
\hline Year FE & YES & YES & YES \\
\hline Importer-Industry FE 6-year periods & YES & YES & YES \\
\hline Exporter-Industry FE 6-year periods & YES & YES & YES \\
\hline
\end{tabular}

Notes: See notes to Table 6 . Standard errors are clustered by destination-year, with ${ }^{* * *},{ }^{* *},{ }^{*}$ denoting significance at the $1 \%, 5 \%$ and $10 \%$ levels, respectively. The regressions include the same control variables as the baseline estimation (see Table 6). 'TangAssets' is demeaned. 


\section{Table A4}

Effects of crises and contract vulnerability on trade across countries and industries: controlling for cyclicality.

Dependent variable: Ln(bilateral sectoral imports)

\begin{tabular}{|c|c|c|c|}
\hline & (1) & $(2)$ & $(3)$ \\
\hline Recession alone & $\begin{array}{c}-0.016^{*} \\
(0.009)\end{array}$ & $\begin{array}{r}-0.016^{*} \\
(0.009)\end{array}$ & $\begin{array}{l}-0.014 \\
(0.009)\end{array}$ \\
\hline Fin.Crisis alone & $\begin{array}{c}-0.044^{* *} \\
(0.019)\end{array}$ & $\begin{array}{c}-0.044^{* *} \\
(0.019)\end{array}$ & $\begin{array}{c}-0.042^{* *} \\
(0.019)\end{array}$ \\
\hline Recession \& Fin.Crisis & $\begin{array}{c}-0.167^{* * *} \\
(0.029)\end{array}$ & $\begin{array}{c}-0.167^{* * *} \\
(0.029)\end{array}$ & $\begin{array}{c}-0.166^{* * *} \\
(0.029)\end{array}$ \\
\hline Recession alone $\times$ Complexity & $\begin{array}{c}-0.038^{* * *} \\
(0.014)\end{array}$ & & \\
\hline Fin.Crisis alone $\times$ Complexity & $\begin{array}{c}-0.082^{* * *} \\
(0.024)\end{array}$ & & \\
\hline Recession \& Fin.Crisis $\times$ Complexity & $\begin{array}{c}-0.184^{* * *} \\
(0.031)\end{array}$ & & \\
\hline Recession alone $\times$ Concentration & & $\begin{array}{c}-0.171^{* * *} \\
(0.026)\end{array}$ & \\
\hline Fin.Crisis alone $\times$ Concentration & & $\begin{array}{c}-0.147^{* * *} \\
(0.044)\end{array}$ & \\
\hline Recession \& Fin.Crisis $\times$ Concentration & & $\begin{array}{c}-0.335^{* * *} \\
(0.057)\end{array}$ & \\
\hline Recession alone $\times$ Uncollectible & & & $\begin{array}{c}-0.174^{* * *} \\
(0.038)\end{array}$ \\
\hline Fin.Crisis alone $\times$ Uncollectible & & & $\begin{array}{l}-0.097 \\
(0.065)\end{array}$ \\
\hline Recession \& Fin.Crisis $\times$ Uncollectible & & & $\begin{array}{c}-0.306^{* * *} \\
(0.077)\end{array}$ \\
\hline Recession alone $\times$ Durables $($ exc. NX) & $\begin{array}{c}-0.014^{* * *} \\
(0.004)\end{array}$ & $\begin{array}{c}-0.013^{* * *} \\
(0.004)\end{array}$ & $\begin{array}{c}-0.028^{* * *} \\
(0.007)\end{array}$ \\
\hline Fin.Crisis alone $\times$ Durables $($ exc. NX) & $\begin{array}{c}0.010 \\
(0.007)\end{array}$ & $\begin{array}{c}0.008 \\
(0.007)\end{array}$ & $\begin{array}{c}0.007 \\
(0.010)\end{array}$ \\
\hline Recession \& Fin.Crisis $\times$ Durables (exc. NX) & $\begin{array}{l}-0.003 \\
(0.009)\end{array}$ & $\begin{array}{l}-0.007 \\
(0.009)\end{array}$ & $\begin{array}{l}-0.002 \\
(0.013)\end{array}$ \\
\hline Observations & $10,853,303$ & $10,853,303$ & $4,132,205$ \\
\hline R-squared & 0.880 & 0.880 & 0.883 \\
\hline Importer-Exporter-Product FE & YES & YES & YES \\
\hline Year FE & YES & YES & YES \\
\hline Importer-Industry FE 6-year periods & YES & YES & YES \\
\hline Exporter-Industry FE 6-year periods & YES & YES & YES \\
\hline
\end{tabular}

Notes: See notes to Table 6. Standard errors are clustered by destination-year, with ${ }^{* * *},{ }^{* *},{ }^{*}$ denoting significance at the $1 \%, 5 \%$ and $10 \%$ levels, respectively. The regressions include the same control variables as the baseline estimation (see Table 6). 